Portland State University

PDXScholar

$6-2-2000$

\title{
Cooking in Eden: Inventing Regional Cuisine in the Pacific Northwest
}

Amy Jo Woodruff

Portland State University

Follow this and additional works at: https://pdxscholar.library.pdx.edu/open_access_etds

Part of the Human Geography Commons, and the Nature and Society Relations Commons Let us know how access to this document benefits you.

Recommended Citation

Woodruff, Amy Jo, "Cooking in Eden: Inventing Regional Cuisine in the Pacific Northwest" (2000). Dissertations and Theses. Paper 4967.

https://doi.org/10.15760/etd.6844

This Thesis is brought to you for free and open access. It has been accepted for inclusion in Dissertations and Theses by an authorized administrator of PDXScholar. Please contact us if we can make this document more accessible: pdxscholar@pdx.edu. 
COOKING IN EDEN:

INVENTING REGIONAL CUISINE

\section{IN THE PACIFIC NORTHWEST}

by

AMY JO WOODRUFF

A thesis submitted in partial fulfillment of the requirements for the degree of

\section{MASTER OF ARTS}

in GEOGRAPHY

Portland State University 2000 


\section{ACKNOWLEDGEMENTS}

I wish to thank my advisor Martha Works for all the support and encouragement she has given me. Her insight, kind words, and enthusiasm for my topic inspired me to keep working on the project even when my own enthusiasm and energy waned. Special thanks go to Barbara Brower for encouraging me to study geography and for inviting me to work on the Himalayan Research Bulletin. Working on the Bulletin has been one of the most meaningful aspects of my graduate studies. I wish to thank Tom Harvey and Bill Lang for their invaluable insight into the Pacific Northwest, and Courtney SullivanVillegas for her friendship and cartographic skills. I wouldn't have finished without her! I also thank my parents for encouraging me to follow my heart and for believing that I will succeed at everything I do. And to my husband Paul I owe the deepest of thanks. His love, friendship, and encouragement has meant more to me than he will ever know. 


\section{THESIS APPROVAL}

The abstract and thesis of Amy Jo Woodruff for the Master of Arts in Geography were presented June 2, 2000, and accepted by the thesis committee and the department.

COMMITTEE APPROVALS:

Martha Works, Chair

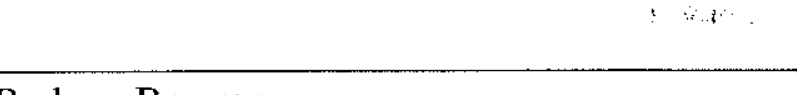

Barbara Brower

Thomas Harvey

William Lang

Representative of the Office of Graduate Studies

DEPARTMENT APPROVAL:

Teresa Bulman, Chair

Department of Geography 


\begin{abstract}
An abstract of the thesis of Amy Jo Woodruff for the Master of Arts in Geography presented June 2, 2000.
\end{abstract}

Title: Cooking in Eden: Inventing Regional Cuisine in the Pacific Northwest

This study examines how regional cuisine is being self-consciously constructed in the Pacific Northwest and discusses the ways in which it contributes to identity in the region. I identify the characteristics - foods, dishes, and culinary practices - of this "new" Northwest cuisine, as well as social and cultural values associated with it, and explore how together they create a sense of regional distinctiveness and loyalty. Because this type of regional cuisine is closely associated with the professional cooking community, I look to restaurants in Portland, Oregon that self-identity as representative of the Pacific Northwest and to regional cookbooks, in order to pinpoint the characteristics of Northwest cuisine and explore their regional associations. I draw on a number of qualitative methods: an analysis of regional cookbooks, a restaurateur survey, interviews with restaurateurs, and a restaurant menu analysis. The use of the region's many specialty agricultural products - berries, orchard fruits, hazelnuts, and 
mushrooms--in meat, game, fish and seafood dishes, as well as salads, are defining aspects of Northwest cuisine. Salmon, more so than any other foodstuff, is the quintessential Northwest food. It is historically significant and has reached iconic status in the Pacific Northwest.

Because of their association with the region's agricultural history and in some cases its cultural history, regional foodstuffs and the dishes they are used in help satisfy a growing hunger for regional identity and a sense of place among Northwesterners. The past these foodstuffs are associated with is idealized and based on the same "Eden" metaphor that brought many settlers to the region during the midnineteenth century. By emphasizing the use of regional foodstuffs rather than a shared culinary history, Northwest cuisine embraces new residents from diverse backgrounds as well as "natives." 


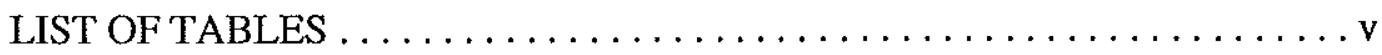

LIST OF FIGURES $\ldots \ldots \ldots \ldots \ldots \ldots \ldots \ldots \ldots \ldots \ldots \ldots \ldots \ldots \ldots$

CHAPTER

I INTRODUCTION $\ldots \ldots \ldots \ldots \ldots \ldots \ldots \ldots \ldots \ldots, \ldots \ldots$

Methodology ......................... 10

Regional Cookbooks

Restaurateur Survey and Follow-Up Interviews

Structure of Paper $\ldots \ldots \ldots \ldots \ldots \ldots \ldots \ldots \ldots 13$

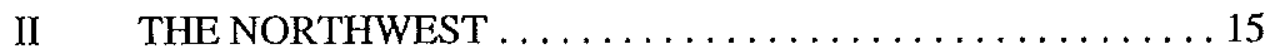

Historic Cultural Geography ............... 15

Historic Foodscape $. \ldots \ldots \ldots \ldots \ldots \ldots \ldots, 16$

Contemporary Cultural Geography . . . . . . . . . . 19

Contemporary Foodscape $\ldots \ldots \ldots \ldots \ldots \ldots \ldots$

III COOKING BY THE BOOK IN THE NORTHWEST ....... 23

Early Northwest Cookbooks ................23

Contemporary Northwest Cookbooks .............25

The Northwest as a Cuisine Region ............ 28

Cuisine in the Northwest $\ldots \ldots \ldots \ldots \ldots \ldots \ldots, \ldots$ 
Foodstuffs and Dishes $\ldots \ldots \ldots \ldots \ldots \ldots \ldots \ldots, \ldots \ldots$

Berries
Orchard Fruits
Hazelnuts
Mushrooms
Beef and Lamb
Game
Seafood
Fish
Salmon
Ethnic Influences and Dishes

Conclusion .........................4 47

IV PORTLAND RESTAURANTS: PURVEYORS OF NORTHWEST REGIONAL CUISINE $\ldots \ldots \ldots \ldots \ldots \ldots 48$

Participating Restaurants $\ldots \ldots \ldots \ldots \ldots \ldots \ldots$

The Northwest as a Cuisine Region . . . . . . . . 53

The Restaurant-Farm Network . . . . . . . . . . 56

Menu Analysis . . . . . . . . . . . . . 58
Regional Dishes
Salmon Dishes
Regional Beverages

Conclusion $\ldots \ldots \ldots \ldots \ldots \ldots \ldots \ldots \ldots, 64$

V CONCLUDING COMMENTS ...................6 65

Inventing Northwest Cuisine...............66

Creating Distinctiveness ..................6 67

Salmon as Icon $\ldots \ldots \ldots \ldots \ldots \ldots \ldots \ldots \ldots, 70$

Northwest Cuisine and Identity $\ldots \ldots \ldots \ldots \ldots \ldots 73$

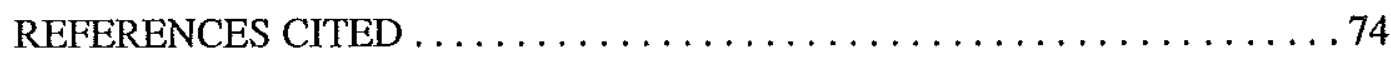


APPENDIX: RESTAURANT SURVEY AND INTERVIEW QUESTIONS . . 82 


\section{LIST OF TABLES}

TABLE

PAGE

I Contemporary Cookbooks Included in Analysis . . . . . . . . 26

II Northwest Dishes that Combine Berries with Chicken,

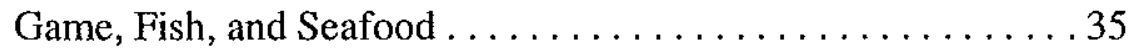

III Northwest Dishes that Combine Fowl and Cherries ........36

IV Participating Restaurants ................52

V Northwest Combinations $\ldots \ldots \ldots \ldots \ldots \ldots \ldots \ldots \ldots \ldots \ldots \ldots$

VI Northwest Salads .....................61

VII Salmon Dishes $\ldots \ldots \ldots \ldots \ldots \ldots \ldots \ldots \ldots \ldots \ldots \ldots \ldots \ldots$ 


\section{LIST OF FIGURES}

FIGURE

PAGE

1. Major Food Producing Areas in the Pacific Northwest . . . . . 21

2. Map of the Pacific Northwest based on Descriptions in

Contemporary Northwest Cookbooks . . . . . . . . . . . . . 29

3. Map of the Pacific Northwest Based on a Compilation of Maps

Drawn by Participants . . . . . . . . . . . . . . 55 


\section{CHAPTER I}

\section{INTRODUCTION}

Few things mean as much to us as food. It is mundane and essential to our survival, yet much of what we eat is not solely to fulfill our physical needs. The food we choose, the way we prepare it, the places we purchase or eat it, and even when we eat it, all provide insight into our social and cultural lives (Gutierrez 1992; Bell and Valentine 1997; Pilcher 1998; Shortridge and Shortridge 1998a). We can make a statement by eating only organic food or by not eating meat. We have the choice of purchasing locally grown produce or food shipped from thousands of miles away. We can elect to comfort ourselves by eating familiar food or sample different cultures by selecting exotic and ethnic food. Our choices-or in some cases, absence of choices-often reflect our family lives and history, lifestyles, cultural background, social and environmental values, education, class, and to an extent, the places we live.

The dizzying variety of food we choose among compounds these choices. Grocery stores stock a world of different food, from flour to Thai fish sauce. Farmers markets, as well as specialty and ethnic grocers, market additional foodstuffs. Restaurants provide access to an international palate of cuisines. Essentially, one can choose food from nearly anywhere around the world and in infinite combinations.

The popularity of ethnic food, both in grocery stores and restaurants, confirms that many choose to do this. Food once foreign, such as pasta and salsa, are now part 
of the rich mosaic of American cuisine, a cuisine that has always been a melting pot. Today the preferred metaphor for this culinary mixing of cultures is fusion. Unlike the melting pot metaphor, fusion emphasizes the unique contributions of each culinary influence.

At the same time there is growing interest in preserving traditional cuisines, in part to placate a fear that they and the cultures they represent will be consumed by homogenization in an increasingly global world. Organizations such as Oldways and Slow Food, as well as the magazine Saveur, help consumers identify traditional cuisines. They describe them as authentic, culturally specific, and place-based. They are also characterized by the use of "fresh, natural, local, slow, rural, [and] artisanal" foods (Laudan 1999, 136).

Both fusion cooking and the increasing interest in traditional cuisines are descendents of French nouvelle cuisine, a style and philosophy of cooking that developed in France during the early 1970s. Nouvelle cuisine emphasizes the importance of rediscovering traditional and regional dishes and at the same time incorporating elements from other culinary traditions into them. Nouvelle cuisine also stresses that complicated and pretentious dishes should be replaced by ones that are simple in preparation, cooked for a minimal amount of time, make use of seasonally available foods, and that are accompanied by stock-based sauces rather than cream (Brenner 1999).

Following the lead of nouvelle cuisine, American chefs began serving dishes based on local and regional foodstuffs that focused on the ingredients themselves 
rather than elaborate preparations in the 1970s (Sokolov 1991). "Fresh" and "local" became the buzzwords of this movement in the United States, which was popularized by Alice Waters and her Berkeley restaurant, Chez Panisse, in the late 1970s (Schnetzer 1999). 'Waters established networks with farmers around the Bay Area in an effort to create a culinary landscape similar to that she found in France. Her chefs created nouvelle type dishes, both fusion and traditional, that were limited to the foodstuffs these farmers could supply seasonally. Although Chez Panisse began as a French restaurant, it eventually became the hotbed for an American version of nouvelle cuisine, what many in the food industry refer to as California cuisine or new American cuisine, and Waters a leading spokesperson for what has become the dominant culinary philosophy of the nation's restaurant community (Beitiks 1999; Brenner 1999).

As this culinary philosophy and style gained in popularity, chefs began to shape it to fit the particulars of their own regions and create "new" versions of regional cuisines (Sokolov 1991). Traditions were revived or constructed, regional ingredients and ethnic influences highlighted, and contemporary versions of regional dishes created. Following the lead of Waters, many restaurateurs and chefs began establishing links with local farmers.

This paper examines how regional cuisine is being self-consciously constructed in the Pacific Northwest and discusses the ways in which it contributes to

\footnotetext{
'Alice Waters was not the only restaurateur creating these types of dishes or who used local produce at this time; however, food writers and chefs generally give her credit for popularizing this culinary philosophy and style (Brenner 1999).
} 
identity in the region. I identify the characteristics—foods, dishes, and culinary practices—of this "new" Northwest cuisine, as well as social and cultural values associated with it, and explore how together they create a sense of regional distinctiveness and loyalty. Because this type of regional cuisine is closely associated with the professional cooking community, I look to restaurants in Portland, Oregon that self-identity as representative of the Pacific Northwest and to regional cookbooks, in order to pinpoint the characteristics of Northwest cuisine and explore their regional associations. Most of the restaurants in Portland that serve Northwest cuisine or regionally inspired dishes are fine dining establishments, thus the dishes they serve tend to resemble more closely special occasion food rather than what is eaten daily in the home. ${ }^{2}$

Many of the dishes that cookbooks highlight are also not everyday food. Cookbooks often showcase the best and finest recipes rather common ones (Pillsbury 1998). To get an understanding of how this contemporary version of Northwest cuisine is similar to or different from earlier incarnations and descriptions of cuisine in the Northwest, I survey regional cookbooks published prior to the development of the new American cuisine movement in the late 1970s.

The underlying premise of this study is that place, food, and identity are linked symbolically. By looking at the construction of a contemporary regional cuisine, geographers can gain a greater understanding of how people create meaning and

\footnotetext{
${ }^{2}$ It is not known what is commonly eaten at home in the region as no studies have addressed this question. Additionally, studies have shown that is difficult to accurately measure daily eating habits (Shortridge and Shortridge 1998b; Thompson and Newman 1999).
} 
context for themselves-in this study's case at the regional level-in a world that is increasingly global and marked by change rather than stability.

Geographers have long been concerned with what distinguishes one place or region from another. More recently, geographers as well as scholars from other disciplines have begun looking at regions as a means of identification and as a medium for social interaction. This "new" regional geography includes the study of cultural identity, social processes, and perception (Murphy 1991; Shortridge 1998). Rather than emphasizing the physical characteristics of a region and the structures associated with it, new regional geography focuses on "how we come to identify with places [or] to know them" (Shortridge 1998, 46), with the understanding that multiple identities often co-exist (Massey 1993). According to historian Patricia Limerick, "regions are much more the creations of human thought and behavior than they are the products of nature" $(1996,96)$, and as geographer Alexander Murphy suggests, "regional settings are ... the results of social processes that reflect and shape particular ideas about how the world is or should be organized" $(1991,24)$. Regions provide a sense of identity based on attributes that distinguish them from other places and regions. These attributes can be physical, cultural, historic, or invented (Shortridge and Shortridge 1998a).

One's understanding of region and subsequently regional identity can also be attributed to a sense of place — an intimate understanding of one's place, locale, or region within larger spaces (Tuan 1980; Murphy 1991; Lippard 1997). This understanding is subjective, personal, and based on lived or imagined experience, and 
"is the geographical component of the psychological need to belong somewhere" (Lippard 1997,7). According to Yi-Fu Tuan (1980), people often look to the past and select unique things to remember, preserve, or establish as a symbol or icon when trying to describe a sense of place. These unique things serve to remind us of who we were and are. James Shortridge (1998) suggests that these images of place or region, even though they may be constructed or far from reality, are important in understanding people's sense of place or their regional attachments, because these images often hold symbolic meaning for people within the region. This study of the Pacific Northwest explores these selected and constructed images and icons, in the form of dishes, foodstuffs, and culinary practices.

Although geographers and other scholars have looked to literature (Pocock 1994), film (Burgess 1994), art (Lippard 1997), and other media in their search to identify regional attributes and symbols, how sense of place is conveyed, and to understand how identity is created or expressed, few have looked at food's relationship to regional identity. Those who have show that food can provide insight into how we understand our place-socially, culturally, and physically-as well as our ideals, lifestyles, and hopes, and how we distinguish ourselves, and our place from others (Bell and Valentine 1997; Kaplan, Hoover and Moore 1998; Shortridge and Shortridge 1998a).

Geographers bring an understanding of the relationship between food, culture, place, and region to the study of foodways, what has traditionally been an ethnographic study of food and culture (Bell and Valentine 1997; Flack 1997; Frenkel 
1998; Shortridge and Shortridge 1998a). They have approached the study of food and culture in a number of ways, from performing spatial analyses of restaurants (Arreola 1983; Kovacik 1998; Zelinsky 1998), to assessing the symbolic resonance of regional and ethnic dishes (Kelly 1998; Frenkel 1998), to identifying patterns of consumption (Shortridge and Shortridge 1989; Grigg 1995). The recent publication of three books on the geography of foodways highlight the growing interest geographers have in this field, as well as the different approaches geographers have taken in the attempt to understand how food and cuisine contribute to or express regional identity (Bell and Valentine 1997; Shortridge and Shortridge 1998c; Pillsbury 1998).

Consuming Geographies: We Are Where We Eat (1997) by British geographers David Bell and Gill Valentine is a meandering discussion of the geography of foodways in which they provide an analytical framework for the study of foodways rather than case studies. In keeping with its geographical theme, each chapter discusses a different spatial scale at which to study food and foodways: body, home, community, city, region, nation, and global. In their chapter dedicated to region, Bell and Valentine suggest researchers follow the lead of new regional geographers by studying how food either expresses or is perceived to express identity, and at the same time is related to larger social forces. They warn scholars to avoid the pitfalls of nostalgia often associated with things regional by acknowledging that much of what we consider regional or traditional is constructed.

This book is postmodernly fashionable; mixed in with the text are short narratives and recipes from famous geographers, including Yi-Fu Tuan's special recipe 
for Top Ramen, as well as photos and other illustrations. More than anything, this work provides geographers theoretical frameworks by which to approach the study of food.

Barbara G. Shortridge's and James R. Shortridge's anthology, The Taste of American Place: A Reader on Regional and Ethmic Foods (1998) provides a chance to survey some of the best literature on foodways. The book is divided into three sections: Regional Foods, Ethnic Foods, and Eating Out. Papers by Stephen Frenkel, Shortridge and Shortridge, Cary W. de Wit, and John A. Milbauer were particularly useful to the creation of my study. Frenkel's piece, "A Pound of Kenya Please, or a Single Short Skinny Mocha," examines the popularity of specialty coffee in the Pacific Northwest and discusses how it fulfills "a nostalgia for the local and the particular" $(1998,61)$. Even though coffee beans are not a regional product, specialty coffee shops are associated with the region, and Seattle most significantly, because it was there that specialty coffee shops first emerged. Frenkel concludes that it is this association that helps specialty coffee satisfy "the nostalgia for regional identity" in the Pacific Northwest $(1998,61)$.

Shortridge and Shortridge include a piece they originally published in the October 1983 edition of the Geographical Review titled, "Patterns of American Rice Consumption 1955 and 1980." They analyze the consumption of rice in different regions and conclude that some regions within the United States have much higher rice consumption than others, particularly those areas with dense immigrant populations who traditionally eat rice. They note a rise in consumption in the West 
and attribute it to a changing image of rice. Rice, as viewed by Westerners, has become associated with "sophistication, youthfulness, and a sense of arcadian antiestablishment" (1998b, 95). Shortridge and Shortridge also suggest that the urbanized West, and California in particular, is the cultural hearth of foodways in the United States.

De Wit's piece, "Food-Place Associations on American Product Labels," surveys place-names on food labels in an attempt to understand if and how the use of place names on food product labels reflects popular perceptions about specific places. He concludes that, "A place reference that appears frequently on labels generally indicates that the place has a strong image-enhancing ability" $(1998,105)$, and that specialty and gourmet foods, more than any other type, frequently use place-names on their labels. He also suggests that there may be a link between particular types of foods and certain lifestyles.

Milbauer's study, "The Geography of Food in Eastern Oklahoma: A Small Restaurant Study," is an attempt to "ascertain the extent to which the diet of eastern Oklahoma as revealed by small eateries reflects the culture of the region, and how it fits into a broader cultural context" $(1998,203)$. Milbauer looked at small neighborhood restaurants and cafes that were unpretentious and catered to a local population-restaurants that did not call attention to themselves in the way that those serving nouvelle or new regional cuisine do. He found that the eating habits of those in eastern Oklahoma are fairly conservative and reflect southern traditions, and that Mexican foods and spaghetti are the only ethnic foods eaten regularly. 
No Foreign Food: The American Diet in Time and Place (1998) by Richard Pillsbury traces the history of food and diet in the United States and looks at how technological changes, mass marketing, immigration, and restaurants have altered how Americans eat and what they think about food. The chapter "Cuisine Regions: Concept and Content" is the most geographical and discusses how cuisine regions have changed over time, and how, despite national and international influences, cuisines retain regional flavor. He identifies six "contemporary diet regions"-the Northeast, the South, the Midwest, the Southwest, the Interior West, and the Pacific West-and discusses the forces which have helped shape food consumption in each of these regions. Like Shortridge and Shortridge (1998b), Pillsbury argues that the West Coast—and again California most significantly—is where the nation's ideas about food and cuisine develop.

Of this growing body of geographic foodways literature, the study of food habits and their cultural context has received the most attention of scholars. Fewer have addressed how a contemporary cuisine helps unite a region.

\section{METHODOLOGY}

To identify the signature ingredients, specific dishes, and preparation techniques that typify Pacific Northwest cuisine, and to explore how these work together to create a sense of regional distinctiveness, I draw on a number of qualitative methods: an analysis of regional cookbooks, a restaurateur survey, interviews with restaurateurs, and a restaurant menu analysis. 


\section{$\underline{\text { Regional Cookbooks }}$}

There is a growing literature of regional American cookbooks (Maryles and Donahue 1999). More than 30 Northwest cookbooks have been published in the last 25 years, whereas few were published prior to the mid-1970s. Some are devoted to places within the region, others to specific foodstuffs, and a number are collections by regional chefs. I limited my inquiry to those that stress a regional approach or style of cooking, because I wanted to measure regional representations of cuisine. In addition to contemporary Northwest cookbooks, I surveyed three early (pre-1975) cookbooks to measure how ideas about Northwest cuisine have changed over time. My survey of early cookbooks was limited because few strictly Northwest regional cookbooks were published before 1975.

I compiled a comprehensive list of dishes from each of the cookbooks and calculated which foodstuffs, combinations of foodstuffs, and dishes appear most frequently. I looked at what ethnic and cultural influences are given the most attention and the ways in which authors address those influences. I also briefly addressed the narrative structure of these cookbooks and the descriptions cookbooks provide of the Northwest and its cuisine. Contemporary regional cookbooks are often more than recipe collections. Many include history, anecdotes, and evocative descriptions and illustrations of places and their foods. According to Pillsbury, these cookbooks are targeted toward advanced cooks or gourmets and "purchased by people who don't cook all that often but do enjoy reading about food" (Pillsbury 1998, 130). 


\section{Restaurateur Survey and Follow-Up Interviews}

I used a brief mail survey that included a mix of closed and open-ended questions to introduce my study to Portland area restaurateurs and ask preliminary questions about their establishments (Appendix). The restaurants I surveyed either self-identify as serving Pacific Northwest cuisine or were described by the Willamette Week's 1998-1999 Restaurant Guide (1998) as serving regional dishes. Most do not identify themselves as exclusively regional; however, they all serve at least one dish that is regionally inspired. Many advertise that they use locally grown produce, thus linking themselves to the regional economy and agricultural landscape.

The survey addressed chefs' and restaurateurs' relationships with local farmers, what foodstuffs or dishes they typically serve, and what percentage of their beer and wine lists is from the Pacific Northwest. I also asked respondents to classify their restaurants and menus in terms of style and regional affiliation, and to list dishes and foodstuffs they consider representative of the Pacific Northwest.

Of the 42 restaurants to which I sent surveys, 14 responded. Eleven of the respondents were interviewed. In addition to these chefs, I interviewed a local food writer and a retired Portland restaurateur. I do not refer to names of interviewees or survey respondents in my paper to preserve the anonymity of participants. I asked each to define the term "regional cuisine" and to describe what, if anything, characterizes Pacific Northwest cuisine, and to explain how it differs from other regional cuisines or American cuisine in general. 
In addition to defining regional cuisine and Pacific Northwest cuisine specifically, I asked them to circle what they thought were American cuisine regions on a map of the United States, even though my study does not address cuisine regions other than the Northwest. By asking them to circle all of the cuisine regions I sought to gauge their perception of the boundaries of the Pacific Northwest without predisposing them to the idea that such a region exists.

I also surveyed menus from participating restaurants to determine which foodstuffs and dishes these restaurants present as Northwestern. As with regional cookbooks, I calculated which foodstuffs and dishes appear the most frequently, and which ethnic and cultural influences are the most prevalent.

The combined use of these qualitative measures provided a detailed description of how regional cuisine is being constructed in the Pacific Northwest and insight into how this cuisine evokes regional identity.

\section{STRUCTURE OF PAPER}

In Chapter II I provide a brief description of the region, its history, and the primary foodstuffs associated with the region's agricultural sector, fisheries, and uncultivated landscapes. This serves to establish a historic precedent for some of the foodstuffs incorporated in contemporary regional cuisine in the Northwest. Chapter III explores how regional cookbooks portray this cuisine. This chapter also addresses the boundaries cookbooks give to the Northwest. Chapter IV details how Portland chefs define regional cuisine in the Northwest and identifies the characteristics they 
and their restaurants associate with it. As I did with cookbooks in Chapter III, I include a description of the boundaries chefs give to the Northwest. Additionally, this chapter describes the relationship between local chefs and farmers in the Portland Metropolitan area. Chapter V is an overview of how Northwest cuisine is being selfconsciously constructed. It reviews the characteristics of Northwest cuisine that are identified both in cooking literature and by chefs, and briefly discusses salmon as a regional icon. This chapter concludes with an analysis of how these characteristics, despite the constructed nature of contemporary regional cuisine in the Northwest, work together to stress regional distinctiveness and provide a means of identity. 


\section{CHAPTER II}

\section{THE NORTHWEST}

For the past 150 years the Pacific Northwest ${ }^{3}$ has been a region of newcomers. Early American settlers were drawn to the region based on the belief that it was some sort of Eden. The Northwest offered the promise of a pastoral life where the fruits of the land were thought to grow without much effort on the part of the farmer and where game, fish, and other wild foods flourished. Subsequent waves of immigrants have also been drawn to the image of the good life that the region evokes. Fewer move to the region today to be farmers, although most enjoy the fruits of the region's agriculture after moving there.

\section{HISTORIC CULTURAL GEOGRAPHY}

Although Europeans first visited the Pacific Northwest in the mid-1500s, it wasn't until the early nineteenth century that European and subsequently American settlement began to take place (Schwantes 1996; Williams 1996). Great Britain's Hudson's Bay Company was established at Fort Vancouver in 1824 and was the first permanent European settlement in the region. Although primarily a fur-trading

${ }^{3}$ As with all regions, the boundaries of the Pacific Northwest are fluid. The Northwest is commonly defined as Oregon, Washington, and Idaho (Schwantes 1996) although some who participated in this study argue that British Columbia, Alaska, and Northern California are also part of this region. Some scholars suggest that the heart of the Northwest lies west of the Cascades because this area is the most densely populated and the bounty associated with the western valleys was what drew settlers to the region (Robbins 1983). For the purposes of this paper, I choose not to set rigid boundaries but recognize that the core of the region rests in Oregon and Washington. 
operation, members were expected to farm during the summer (Nolan 1993). The company became the first commercial agricultural endeavor in the region and at its height cultivated 6,000 acres (Scott and De Lorme 1988). Additionally, a number of retired Hudson's Bay employees started farms on Sauvie Island and throughout the Willamette Valley (Dicken and Dicken 1979; Schwantes 1996).

In the early 1840 s sizable numbers of immigrants began settling in the region. Almost all the American pioneers who moved to the Northwest at this time were Protestants and the majority were farmers (Schwantes 1996). They came from the Mid-Western states of Illinois, Indiana, Iowa, Kentucky, Missouri, Ohio, and Tennessee, as well as the Mid-Atlantic and New England. Foreign born immigrants came from China, Japan, Mexico, Scandinavia, Germany, Ireland, and the Basque region of Spain and France (Dicken and Dicken 1979). The completion of the transcontinental railroad brought yet another wave of immigrants to the Northwest. Between 1880 and 1910 the combined population of Oregon, Washington, and Idaho grew from 283,0000 to $2,227,000$ (Findlay 1997).

\section{HISTORIC FOODSCAPE}

Most of the people who moved to the Pacific Northwest in the nineteenth century came to farm. Early agriculture took the form of dairy farming, cattle ranching, wheat production, market gardening, and orchard cultivation (Dicken and Dicken 1979). Soon after establishing themselves in the Pacific Northwest settlers planted gardens from seeds they had carried with them or that they purchased after 
arriving. They also planted apples, pears, plums, and other orchard fruits as soon trees became available to them. ${ }^{4}$ According to Dale Brown, author of American Cooking: The Northwest (1970), "the Northwest's fruit industry grew out of the homesickness of the people who first settled there. This remote corner of Western America was a new and alien world to them, and they missed the cultivated fruit they had taken for granted back home" (p. 78).

Commercial agriculture developed after settlers had a chance to secure food for their own subsistence. The first commercial hazelnut orchard was planted in Oregon in 1876 (Page-English 1992) and in the late 1880s, Italian farmers in Walla Walla, Washington began growing sweet onions-now known as Walla Walla Sweets--that were introduced to them by a French immigrant Peter Pieri (Walla Walla Sweet Onion Commission, n.d.). By the early 1900s raspberries and strawberries were established as commercial agricultural commodities in western Washington and Oregon (Morgan 1992).

Northwest Native Americans traditionally relied upon wild, not cultivated foodstuffs. They encouraged growth of specific foodstuffs-bracken ferns, edible bulbs, and berries-by periodically setting fire to the grasses that dominated the western valleys of Oregon and Washington. Seafood and fish were plentiful and easily gathered, and thus central to coastal Native American populations, as well as early settlers. Salmon, arguably the most significant foodstuff to Northwest Native

\footnotetext{
${ }^{4}$ The first nursery in Oregon was established near Oregon City in 1847 by Henderson Luelling. Luelling came to the Oregon Territory from Iowa with several hundred grafted fruit trees, as well as grape and berry bushes (Cardwell 1906).
} 
Americans, reached deep within the region via the Columbia River and its tributaries (Williams 1996). It was used as a trade commodity and as a staple food source. When fresh salmon was available Native Americans often butterflied a whole fish and cooked it over a fire, preferably one made from alder. They also prepared salmon by roasting it in a shallow open pit or by baking it in a deeper pit lined with hot stones and covered for 12 to 24 hours. At times these stones were covered with moss or other greens to provide flavoring or the salmon was wrapped in cedar bark. This technique was an easy way to prepare a large quantity of fish at one time and was often used at potlatches. Most of the year Northwest Native Americans relied on dried or smoked salmon that had been left to air dry on wooden racks or smoked over alder, poplar, or cottonwood chips (Fussell 1997).

Before merchants established a presence in the Northwest, early EuropeanAmerican settlers relied on foods they could grow or forage. Settlers were less than eager to adopt cooking styles common to Native Americans in the region, but incorporated many of the native foodstuffs-berries, wild greens, game, and fish--into their diets. They did not, however, incorporate unfamiliar native plants such as camas. These foodstuffs were eaten seasonally and preserved to the extent that they could be. Fruits and berries were dried or made into jams, jellies, butters or leathers, and meats were dried, salted, or brined (Williams 1996).

More than anything settlers preferred familiar foods and recipes. According to Jacqueline Williams, author of The Way We Ate: Pacific Northwest Cooking, $1843-$ 1900 (1996), settler women were determined to provide their families with meals 
equivalent to ones they left behind. Pies were made from venison, dried berries, and sorrel. Those living near the ocean found an abundance of shellfish including clams, crabs, and oysters. Dishes such as fried clams, clam chowder, and clam fritters were staples. Oysters were used in soups, stews, chowders, fritters, and occasionally pies. Fresh fish including cod, halibut, smelt, sturgeon, steelhead, and salmon were broiled, baked, fried, steamed, or stewed (Williams 1996).

\section{CONTEMPORARY CULTURAL GEOGRAPHY}

The Pacific Northwest continued to experience population growth in the twentieth century. The most significant growth occurred in Washington state (Matzke 1993); however, Oregon experienced rapid growth during the late 1980s and early 1990s (Center for Population Research and Census 1994). The Northwest has become a destination for emigrants from California (Steiner and Wrobel 1997), as well Asian and Latin American immigrants. Changes in immigration laws, particularly the passage of the 1965 Immigration Act, have allowed greater numbers of Asian and Latin American immigrants to come to the United States; many chose to come to the Pacific Northwest (Brenner 1999; Matzke 1993). Increased economic and cultural ties with Asia have also encouraged more Asian migration to the region. Cuisine in the region is beginning to reflect these influences despite the fact the Pacific Northwest remains a largely Caucasian region (Findlay 1997). Cuisine is still based on the foodstuffs that were part of the region's early foodscape but as Chapter III and Chapter 
IV will discuss, they are often accented by Asian, Latin American, and other culinary influences.

\section{CONTEMPORARY FOODSCAPE}

Today the Pacific Northwest is well known for its agricultural and natural resources. The climatic and physiographic diversity of the Northwest enable the region to produce a wide variety of foodstuffs, both wild and cultivated (Figure 1). The most fertile food producing areas are west of the Cascades where the climate is temperate and the soils rich. Coastal areas are wet and mild, and support dairies and cheese factories, and wild fisheries as well as aquaculture production. The western lowlands of the Willamette Valley and the Puget Sound have warm dry summers and mild wet winters, and unlike eastern Oregon and Washington, farms in the Willamette Valley and the Puget Sound are small-scale and grow many of the specialty foodstuffs associated with the region, such as hazelnuts and berries. The Rogue River Valley in southwestern Oregon grows a significant percentage of the region's pears.

Wild foodstuffs such as mushrooms, fiddlehead ferns, and game flank the lower elevations of the Cascades, which receive significant precipitation during the winter months, and have temperatures that vary significantly by elevation and aspect, year round. To the east, summers are hotter and winters cooler, and precipitation is slight. Because of irrigation these areas are able to support some of the region's largest farming operations. Wheat and other grains, legumes, mint, and orchard fruits are all products of this irrigated landscape. The Yakima, Okanogan, and Hood River valleys grow nearly all the nation's apples and a significant percentage of its pears and 


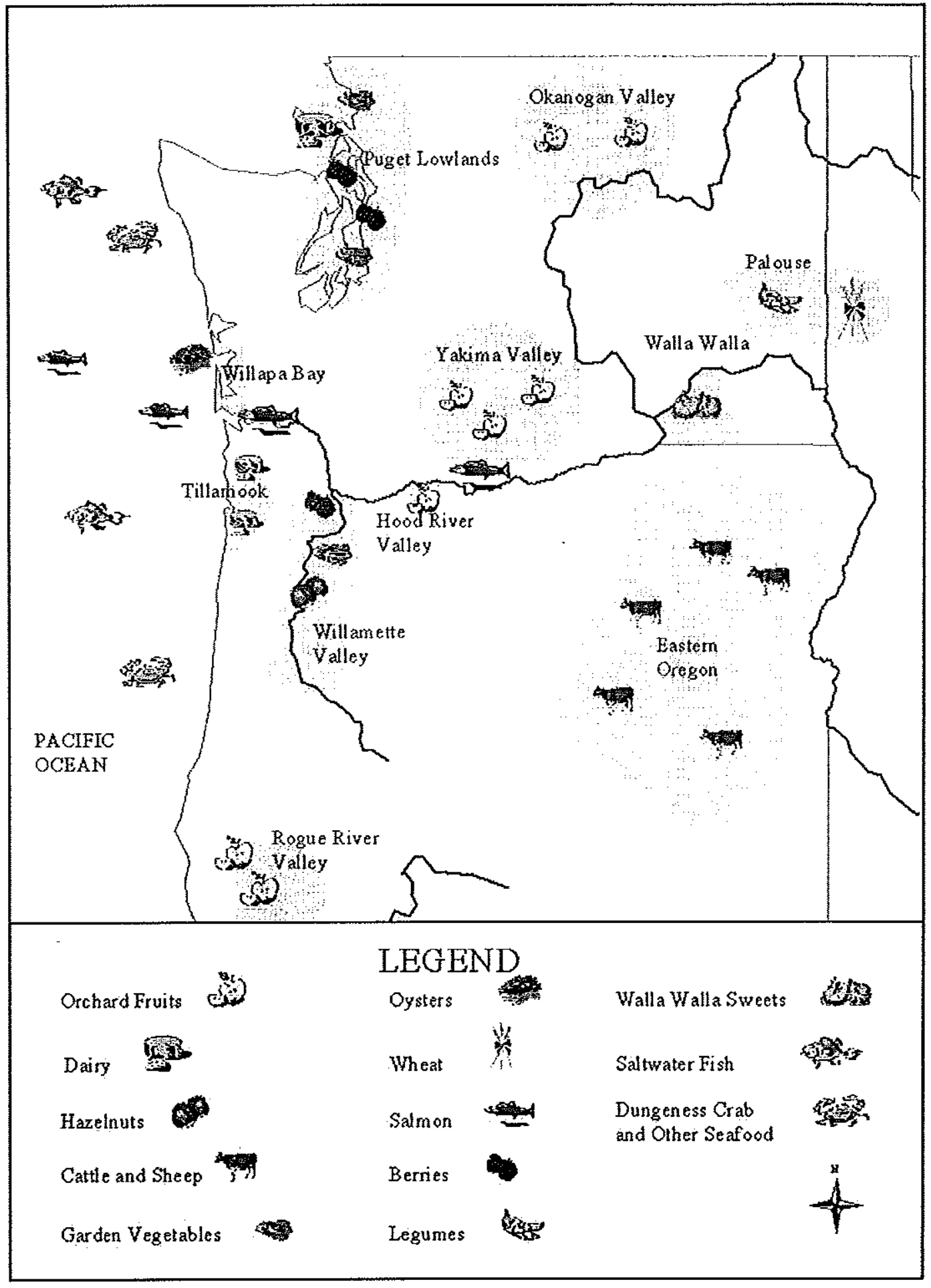

Figure 1: Major Food Producing Areas in the Pacific Northwest 
sweet cherries (Korn 1999; Washington Department of Agriculture 1999). Beef and lamb graze on the non-irrigated rangelands east of the Cascades.

These foods, both the indigenous foodstuffs and those introduced to the region by settlers, reflect the cultural and culinary traditions of the native population, the early settlers, as well as later immigrants. They also form the building blocks of contemporary cuisine in the region. 


\section{CHAPTER III}

\section{COOKING BY THE BOOK IN THE NORTHWEST}

Cookbooks can be many things: recipe collections, family memoirs, instruction manuals, guidebooks, and at times, histories. They range from self-published family and community collections to slick coffee table books and encyclopedic treatises. Most cookbooks contain recipes for dishes that are not necessarily prepared daily; however, these special occasion foods often are more representative of, or most closely associated with, our perceptions of cuisine and identity. In addition to the their content, the structure of cookbooks tells us something about the ideas behind the food or cuisine the cookbook is describing. For example, a cookbook organized around seasons emphasizes the seasonal nature of foods and dishes. Cookbooks also reveal the fashion of the day, and when compared over time one can see how tastes, as well as ideas about food consumption and production, have changed.

\section{EARLY NORTHWEST COOKBOOKS}

To get a sense of how ideas about Northwest cuisine have changed over time and to compare how Northwest cuisine is described or constructed before and the new American regional cuisine movement came into force in the 1970 s, I include three early (pre-1975) regional cookbooks in my analysis, in addition to thirteen contemporary (post 1975) ones. My analysis of early cookbooks is limited to these three because few with a specifically regional focus were published before 1975 . Of 
these three only one, Mary Cullen's Northwest Cook Book (1946), focuses on the Pacific Northwest exclusively. The geographic reach of the other two, the Sunset AllWestern Cook Book (1935) and Helen Brown's West Coast Cook Book (1952) extend beyond the Pacific Northwest to all of the Western states and the West Coast, respectively, and neither includes British Columbia. Both are heavily weighted towards California and only briefly reflect on Oregon and Washington's contributions, primarily of seafood.

Mary Cullen's Northwest Cook Book (1946) and Helen Brown's West Coast Cook Book (1952) are typical of this period. They are organized by type of dish or course and contain very little commentary or additional information about the foods and dishes presented. The Sumset-All Western Cook Book (1935) is an exception; its focus is on individual foodstuffs and ways they can be prepared, and on information about where, how, and in what season to obtain them. Its list of foodstuffs is exhaustive and includes many that one might find on menus of upscale restaurants in the region today, including celeriac, chard, escarole, kohlrabi, as well as games meats such as duck, venison, and rabbit. It is designed to be a manual for western living. Like its affiliate magazine, Sunset, ${ }^{5}$ the purpose of this cookbook was "To help you who live in the West to enjoy more fully the glorious products of these Western states; to introduce you, perhaps, to some of the less well known foods of particular

\footnotetext{
${ }^{5}$ In a study comparing the influence of Sunset and Southern Living magazines on gardens in the West and the South, geographer Peirce Lewis describes Sunset as having "a kind of scriptural authority" with readers, and states that "it would never occur to most readers to question the accuracy of or reliability of the editorial content" $(1990,119)$. He also says that Sunset has one "persistent message: you can learn how to live as a westerner" (Lewis 1990, 124).
} 
localities; in short, to help you live more abundantly here in the West" (Callahan 1935, ii). In many ways the Sunset book was before its time. Its structure, as well as the inclusion of auxiliary information in addition to recipes, is much like that of contemporary Northwest cookbooks.

\section{CONTEMPORARY NORTHWEST COOKBOOKS}

Contemporary regional cookbooks often include descriptions of the region's geography and history, and touch on regional metaphors and symbols to help tell their stories, in addition to providing information about regional foodstuffs and dishes. Some even refer to particular places or locales in recipe names. They are not simply cooking books, but rather, books designed for readers interested in learning more about specific foodstuffs, the history of these foodstuffs, and the human and physical landscapes with which they are associated; thus, providing insight into how regions are viewed and understood by insiders, and how these insiders (the authors) want others to perceive the region.

All of the contemporary Northwest cookbooks I surveyed fit this model to a degree (Table I). Janie Hibler's, Dungeness Crabs and Blackberry Cobblers: The Northwest Heritage Cookbook (1996) is perhaps the best example of this type of cookbook. Hibler takes readers on a culinary journey through the history of the Pacific Northwest. She begins with a brief description of the Pacific Northwest's physical attributes, its primary foodstuffs, and its cultural history, as well as her experience growing up in the region. Each chapter is introduced with a brief essay 
TABLE I

CONTEMPORARY COOKBOOKS INCLUDED IN ANALYSIS

\begin{tabular}{|l|l|l|}
\hline TITLE & AUTHOR(S) & DATE \\
\hline $\begin{array}{l}\text { Dungeness Crabs and Blackberry Cobblers: } \\
\text { The Northwest Heritage Cookbook }\end{array}$ & Janie Hibler & 1996 \\
\hline $\begin{array}{l}\text { Eating Well: A Guide to Foods of the Pacific } \\
\text { Northwest }\end{array}$ & John Doerper & 1984 \\
\hline Food and Wine of the Pacific Northwest & John Sarich & 1993 \\
\hline $\begin{array}{l}\text { Food for All Seasons: Savory Recipes from } \\
\text { the Pacific Northwest }\end{array}$ & David Pisegna & 1990 \\
\hline $\begin{array}{l}\text { The Northwest Best Places Cookbook: } \\
\text { Recipes from the Outstanding Restaurants } \\
\text { and Inns of Washington, Oregon, and British } \\
\text { Columbia }\end{array}$ & $\begin{array}{l}\text { Cynthia C. } \\
\text { Nims and Lori }\end{array}$ & 1996 \\
\hline $\begin{array}{l}\text { Northwest Bounty: A Cookbook Celebrating } \\
\text { the Extraordinary Foods of the Pacific } \\
\text { Northwest, revised edition }\end{array}$ & $\begin{array}{l}\text { Schuyler Ingle } \\
\text { and Sharon } \\
\text { Kramis }\end{array}$ & 1999 \\
\hline $\begin{array}{l}\text { The Northwest Cookbook: Living with } \\
\text { Abundance in the Pacific Northwest }\end{array}$ & Lila Gault & 1978 \\
\hline $\begin{array}{l}\text { The Northwest Essentials Cookbook: } \\
\text { Cooking with the Ingredients that Define a } \\
\text { Regional Cuisine }\end{array}$ & Greg Atkinson & 1999 \\
\hline $\begin{array}{l}\text { Northwest Food and Wine: Great Food to } \\
\text { Serve with the Wines of Oregon and } \\
\text { Washington }\end{array}$ & $\begin{array}{l}\text { Dan Taggart } \\
\text { and Kathleen } \\
\text { Taggart }\end{array}$ & 1998 \\
\hline $\begin{array}{l}\text { Oregon's Cuisine of the Rain: From Lush } \\
\text { Farm Foods to Regional Recipes }\end{array}$ & Karen Brooks & 1993 \\
\hline $\begin{array}{l}\text { Pacific Northwest Flavors: 150 Recipes from } \\
\text { the Region's Farmland, Coastline, } \\
\text { Mountains, and Cities }\end{array}$ & $\begin{array}{l}\text { Michael Skott } \\
\text { and Lori } \\
\text { McKean }\end{array}$ & 1995 \\
\hline $\begin{array}{l}\text { Pacific Northwest the Beautiful Cookbook: } \\
\text { Authentic Recipes from the Pacific } \\
\text { Northwest }\end{array}$ & $\begin{array}{l}\text { Kathy Casey, } \\
\text { editor }\end{array}$ & 1993 \\
\hline $\begin{array}{l}\text { Tastes of the Pacific Northwest: Traditional } \\
\text { and Innovative Recipes from America's } \\
\text { Newest Regional Cuisine }\end{array}$ & $\begin{array}{l}\text { Fred Brack and } \\
\text { Tina Bell }\end{array}$ & 1988 \\
\hline
\end{tabular}


related to the foodstuffs included in it. In addition to recipes, Hibler includes historical anecdotes, photographs, and menus, as well as information about specific foodstuffs and their role in the region's uncultivated and agricultural landscapes. She occasionally includes details about the origins of particular recipes and attributes some recipes to individuals, and others to cultural groups. As in all the contemporary cookbooks, her recipes center on foodstuffs common to or representative of, the Pacific Northwest.

Pacific Northwest the Beautiful Cookbook (1993), edited by Kathy Casey, has a geographic narrative rather than a historical one like Hibler's. Casey introduces each chapter with an essay describing the Northwest's primary food-producing regions and includes many maps and full-color photographs. These photographs evoke a sense of place by highlighting the physical landscapes of the region, quaint restaurants and outdoor markets, as well as signature foods. Together these essays and illustrations portray a region rich in food resources and that is both pastoral and wild.

Other cookbooks in my survey also have geographic narratives (Brack and Bell 1988; Skott and McKean 1995), as well as chapters built around the seasons (Gault 1978; Pisegna 1990; Sarich 1993), regional foodstuffs (Doerper 1984; Brooks 1993; Ingle and Kramis 1999; Atkinson 1999), the pairing of regional wines and food (Taggart and Taggart 1998), and dishes served at popular restaurants and inns in the Northwest (Nims and McKean 1996).

Many of these cookbooks give short descriptions of the cultural influences that have most significantly influenced Northwest cuisine. They also provide tips about 
where to purchase particular foodstuffs or how to harvest, catch, or gather them, in addition to instructions on how to prepare them. It is expected that the reader is interested, willing, and able to prepare dishes from "scratch," and shares the author's belief in the superiority, and thus necessity, of fresh, local foodstuffs. Local foodstuffs are at the heart of all these cookbooks despite differences in narrative structure. Additionally, all of the cookbooks portray a similar vision of the Northwest. They portray it as a region that is noted for its physiographic and cultural diversity, and for its bountiful foods.

\section{THE NORTHWEST AS A CUISINE REGION}

All the contemporary cookbooks I surveyed focused on the Pacific Northwest exclusively although their definitions of the Northwest vary (Figure 2). ${ }^{6}$ All agree that the heart of the Pacific Northwest is in Oregon and Washington. Others include British Columbia (Gault 1978; Doerper 1984; Brack and Bell 1988; Pisegna 1990; Casey 1993; Skott and McKean 1995; Nims and McKean 1996), and Idaho (Ingle and Kramis 1999; Atkinson 1999). All but one (Sarich 1993) exclude Alaska in their definition of the Pacific Northwest and only one includes Northern California (Hibler 1996).

The Northwest these cookbooks describe is Eden-like, verdant, and near utopian when it comes to food production. According to Casey (1993), "The diverse

\footnotetext{
${ }^{6}$ The boundaries of the Pacific Northwest are fuzzy and do not necessarily correspond to the state boundaries delineated on this map; however, cookbooks in my survey defined boundaries by state lines.
} 


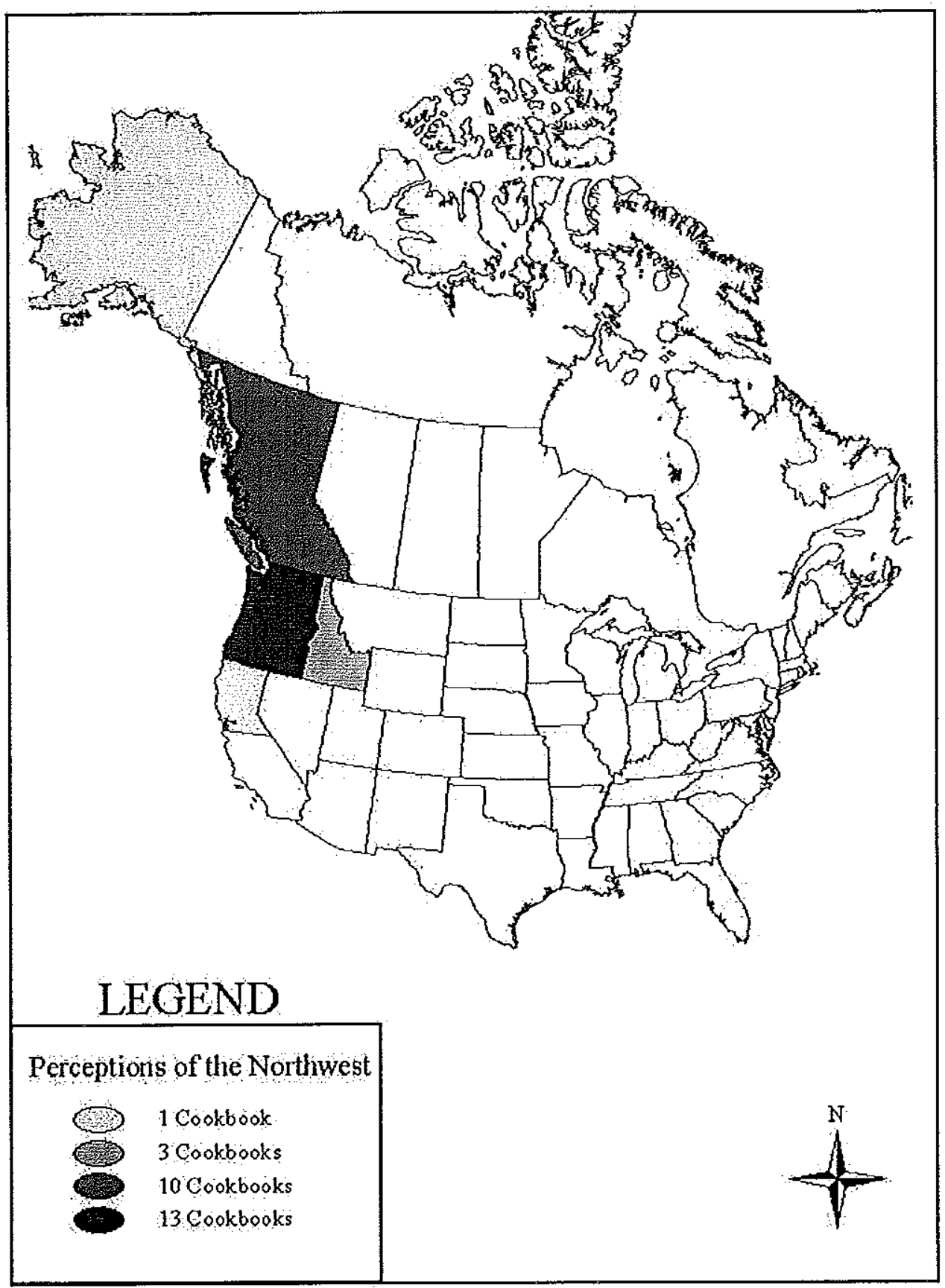

Figure 2. Map of the Pacific Northwest based on Descriptions in Contemporary Northwest Cookbooks 
landscapes of the Pacific Northwest-ocean beaches and inland coves, steaming volcanoes and rolling hillsides thick with wheat, rain forest moss and desert tumbleweed-provide an equivalent diversity of great food" (p. 17). Michael Skott and Lori McKean, authors of Pacific Northwest Flavors (1995), further illustrate this by describing how specific foodstuffs are associated with particular areas within the region:

Many of the flavors associated with the Pacific Northwest cuisine evoke the beauty of the untamed land, rivers, lakes, sounds, and ocean. Buttery rich salmon is fruity and musty, redolent of the deep sea, while delicate seafoods like Dungeness crab, scallops, halibut, and perch sparkle with sweet, clean, oceanic flavors. Juicy berries burst in the mouth, releasing flavors of hot summer sun and evergreen-scented air. Wild mushrooms taste earthy and sweet like the decaying loam of the forest floor. Oysters smack of briny saltwater bays and crisp minerals, and wild game resounds with the hearty, robust flavors of the dense forests and rugged mountains (p. 8-9).

Casey, Skott, and McKean make it clear that the diverse landscape of the Pacific Northwest is intimately linked to the region's cuisine and subsequently, the lives of Northwesterners.

\section{CUISINE IN THE NORTHWEST}

Northwest cuisine, as described by contemporary Northwest cookbooks, is characterized as simple in preparation and seasonal in focus (Pisegna 1990). It is subtle and "based on natural flavors and on sauces, condiments, and spices which enhance those flavors" rather than "blending them together into an amorphous whole" (Doerper 1984, 17), much like nouvelle cuisine or California cuisine. John Sarich, author of Food and Wine of the Pacific Northwest (1993) describes it as "fresh, 
versatile and highly flavored" (p. 4) It also "reflects the region's abundance of fresh foods and its multi-ethnic population" (Sarich 1993, 4).

David Pisegna, in Food for All Seasons: Savory Recipes from the Pacific Northwest (1990), describes cuisine in the Pacific Northwest as a "donation stew" rather than a melting pot, a stew built upon the contributions of Native Americans, the pioneers, and every other cultural group that has come to Northwest, including Russian, Chinese, Japanese, Vietnamese, Thai, Korean, Spanish, Mexican, French, Canadian, English, German, Croatian, Basque, Norwegian, and Danish. Hibler (1996) provides a similar definition of Northwest cuisine. She describes it as a mosaic built upon the contributions of Native Americans, French-Canadian and English explorers, settlers from the South and Midwest, many of whom were of German, British, or Scandinavian descent, as well as Asian immigrants (predominately Chinese, Japanese, Vietnamese, and Thai), all of whom have influenced the culinary climate in the region by introducing new foodstuffs and dishes. She credits Northwest Native Americans with having the most significant impact on cuisine in region. They taught settlers about native foodstuffs, including berries, mushrooms, greens, and other edible plants. Lisa Gault, author of The Northwest Cookbook (1978), also pays homage to Native Americans, "to whom credit should be properly given for what most Americans consider the quintessential Northwest feast-the salmon barbecue" (p. 2). These descriptions of the culinary and cultural contributions of the region's native populations, as well as that of immigrants, leave readers with the impression that the region's cuisine gives equal weight to each of these contributions, whereas in reality 
the dominant influences are Northern European and Mediterranean. The emphasis on cultural contributions is perhaps a reflection of contemporary sentiment that values diversity rather than hegemony.

Despite these descriptions most authors acknowledge that the region is relatively young, and that what they describe as regional cuisine in the Pacific Northwest is in its infancy. According to Schuyler Ingle and Sharon Kramis, authors of Northwest Bounty (1999):

There's still no regional cuisine in the Pacific Northwest the way there is in New Orleans or Santa Fe. But there is a style, a way with food not hounded by tradition. Everybody but the Indians arrived in the Pacific Northwest too recently for regional traditions of any great meaning to have taken hold (p. viii).

Many cookbooks authors have found it easier to describe how Northwest foodstuffs can be used to give dishes a regional flavor rather than to pin down particular dishes that represent Northwest cuisine. There is not a Northwest equivalent to Southern grits. However, upon surveying recipes in both early and contemporary cookbooks, I found a number of types of dishes or combinations of foodstuffs that appeared repeatedly as well as clusters of ethnic foods.

\section{FOODSTUFFS AND DISHES}

The Northwest's palate of foodstuffs remains virtually the same as it was 100 years ago. It is a mix of wild and cultivated foodstuffs. Some are indigenous, others were brought here by settlers and immigrants. They include berries, orchard fruits, hazelnuts, mushrooms, game, beef, lamb, shellfish and other seafood, and of course, 
salmon. Most are not extraordinary or limited to the Pacific Northwest; however, the ways they are combined with one another make the region's cuisine distinctive.

Berries and fruits are served with meats, fish, and seafood. Hazelnuts-known mostly as a dessert ingredient by the rest of the world-are used in everything from salads to salmon bakes. Mushrooms, both wild and cultivated, appear in recipes so often that at times it seems one cannot have a Northwest dish without them. Many recipes are familiar and hardly seem regional, but when plated with one or more of the region's specialty foodstuffs-berries, hazelnuts, mushrooms, Walla Walla Sweet Onions, wine, or cheese-they are transformed into something that cookbook authors feel is distinctly Northwestern.

$\underline{\text { Berries }}$

Regional cookbooks, particularly contemporary ones, are full of berry recipes. Blackberry recipes are the most common with variations that include Marionberries, boysenberries, and loganberries. Cobblers and pies are the most popular blackberry desserts. Out of all the cookbooks I surveyed, there are six different blackberry cobbler recipes (Brooks 1993; Casey 1993; Doerper 1984; Hibler 1996; Brack and Bell 1988) and five pie recipes (Brown 1952; Sarich 1993; Skott and McKean 1995; Hibler 1996; Ingle and Kramis 1999). Other desserts include tarts, tortes, crisps, sorbets, cakes, and ice cream.

Raspberries and strawberries are represented among the desserts but to a lesser extent. Strawberries are often featured in desserts with rhubarb-a common 
pairing — or in open-faced pies and tarts. Raspberries, like strawberries, are delicate and do not hold up well when cooked. They too are frequently used in tarts, as well as toppings for cakes.

Even though huckleberries are one of the Northwest's best-known wild berries only five of the cookbooks (Casey 1993; Brooks 1993; Skott and McKean 1995;

Hibler 1996; Ingle and Kramis 1999) include recipes that call for them specifically. One such recipe is "Huckleberry Slump" (Casey 1993; Ingle and Kramis 1999), a "colonial New England specialty that has become a part of the culinary tradition of the Pacific Northwest" (Ingle and Kramis 1999, 194).

Berry desserts are by far the most common desserts featured in contemporary cookbooks, suggesting that the ideal Northwest dessert is berry based; the popularity of cobblers suggests that simple preparations are preferred. However, berries are not limited to desserts. They are often used as an accent or accompaniment to chicken, fish, game, and seafood, and in conjunction with other Northwest foodstuffs such as mushrooms and hazelnuts (Table II). These combinations illustrate how cookbook authors use regional foodstuffs, alone or in combination, to give dishes a regional connection, something that occurs repeatedly throughout contemporary cookbooks.

\section{Orchard Fruits}

Contemporary cookbooks also feature many non-dessert recipes for orchard fruits — cherries, plums, peaches, pears, and apples. They are used in salads and as accompaniments to meats, fish, and game, and are often used in conjunction with 
TABLE II

NORTHWEST DISHES THAT COMBINE BERRIES

WITH CHICKEN, GAME, FISH, AND SEAFOOD

\begin{tabular}{|c|c|c|}
\hline BERRY & DISH & AUTHOR \\
\hline \multirow[t]{8}{*}{ Blackberry } & $\begin{array}{l}\text { Perfect Oven-Broiled Salmon with } \\
\text { Blackberry Butter Sauce }\end{array}$ & Atkinson 1999 \\
\hline & Duck with Wild Blackberry Sauce & Brooks 1993 \\
\hline & $\begin{array}{l}\text { Pasta with Nehalem Bay Crab and } \\
\text { Blackberries }\end{array}$ & Brooks 1993 \\
\hline & $\begin{array}{l}\text { Duck Breast with Wild Blackberries and } \\
\text { Ginger }\end{array}$ & Casey 1993 \\
\hline & Steamed Halibut with Blackberry Butter & Casey 1993 \\
\hline & $\begin{array}{l}\text { Roast Chicken with Barley-Mushroom } \\
\text { Stuffing in Blackberry Sauce }\end{array}$ & Hibler 1996 \\
\hline & $\begin{array}{l}\text { Hazelnut Chicken Breasts with Berry } \\
\text { (Blackberry and Raspberry) Sauce }\end{array}$ & $\begin{array}{l}\text { Nims and } \\
\text { McKean } 1996\end{array}$ \\
\hline & $\begin{array}{l}\text { Sooke Trout Baked in Parchment with } \\
\text { Spinach and Blackberry Sauce }\end{array}$ & $\begin{array}{l}\text { Nims and } \\
\text { McKean } 1996\end{array}$ \\
\hline \multirow{4}{*}{ Raspberry } & Breasts of Chicken with Raspberries & Atkinson 1999 \\
\hline & $\begin{array}{l}\text { Chicken Breasts with Raspberry- } \\
\text { Teriyaki Sauce }\end{array}$ & $\begin{array}{l}\text { Brack and Bell } \\
1988\end{array}$ \\
\hline & $\begin{array}{l}\text { Roast Chicken with Shiitake } \\
\text { Mushrooms and Fresh Raspberries }\end{array}$ & Hibler 1996 \\
\hline & $\begin{array}{l}\text { Smoked Quail with Raspberry-Mustard } \\
\text { Sauce }\end{array}$ & Hibler 1996 \\
\hline Huckleberry & $\begin{array}{l}\text { Seared Sea Scallops with Huckleberry- } \\
\text { Lavender Vinaigrette and Chanterelle } \\
\text { Salad }\end{array}$ & $\begin{array}{l}\text { Nims and } \\
\text { McKean } 1996\end{array}$ \\
\hline \multirow[t]{4}{*}{ Cranberry } & $\begin{array}{l}\text { Duck Breast on Potato Pancakes with } \\
\text { Cranberry Vinaigrette }\end{array}$ & $\begin{array}{l}\text { Brack and Bell } \\
1988\end{array}$ \\
\hline & $\begin{array}{l}\text { Grilled Venison with Cranberry-Pepper } \\
\text { Sauce }\end{array}$ & Brooks 1993 \\
\hline & $\begin{array}{l}\text { Planked White King Salmon with } \\
\text { Cranberry Relish }\end{array}$ & Casey 1993 \\
\hline & $\begin{array}{l}\text { Grilled Fillet of Sturgeon with } \\
\text { Chanterelles and Cranberry-Port Cream } \\
\text { Sauce }\end{array}$ & $\begin{array}{l}\text { Ingle and } \\
\text { Kramis } 1999\end{array}$ \\
\hline Strawberry & Halibut with Strawberry Mint Salsa & Casey 1993 \\
\hline
\end{tabular}


other regional foodstuffs. One popular combination that is found in both early and contemporary cookbooks is fowl prepared with cherries (Table III). Other fruit and fowl recipes include "Duck Breast with Plum Sauce" (Brack and Bell 1988), "Braised Pheasant with Yakima Valley Hard Cider and Apples" (Casey 1993), "Baked Pheasant with Morels, Peaches, and Cream" (Hibler 1996), and "Quail with Chestnut Stuffing and Warm Pears" (Brooks 1993). In addition to fowl, orchard fruits accompany fish and seafood in recipes such as, "Pan Roasted Steelhead with Apples, Onions, and Sage" (Casey 1993), "Fillet of Salmon Sautéed with Granny Smiths and Cider" (Atkinson 1999), and "Crab Cakes with Aged Cheddar and Pear Chutney" (Brooks 1993).

TABLE III

NORTHWEST DISHES THAT COMBINE FOWL AND CHERRIES

\begin{tabular}{|l|l|}
\hline DISH & AUTHOR \\
\hline $\begin{array}{l}\text { Breast of Duckling with Tart Cherry Sauce, } \\
\text { Caramelized Onions, and Grilled Polenta Rounds }\end{array}$ & Atkinson 1999 \\
\hline Duck with Sweet Cherries & $\begin{array}{l}\text { Brack and Bell } \\
1988\end{array}$ \\
\hline Roast Pheasant with Cherries & Brown 1952 \\
\hline Chicken with Cherries & Gault 1978 \\
\hline Spit-Roasted Chicken with Cherry Chutney & Pisegna 1990 \\
\hline Wild Duck with Cabernet Sauvignon Chukar & Sarich 1993 \\
Cherry Sauce & $\begin{array}{l}\text { Skott and McKean } \\
1995\end{array}$ \\
\hline Dried Cherry Marinated Chicken & $\begin{array}{l}\text { Skott and McKean } \\
1995\end{array}$ \\
\hline Risotto with Duck and Dried Cherries & Taggart and \\
& Taggart 1998 \\
\hline Sautéed Duck Breast with Dried-Cherry Sauce & \\
\hline
\end{tabular}


Pears and apples are quintessential elements of Northwest salads, whether they are one of the primary ingredients or simply a garnish or topping. Many of these salads also include regional cheeses or nuts, and the dressing of choice is vinaigrette. Nims and McKean's (1996), "Endive and Hood River Apples with Spiced Pecans, Goat Cheese, and Sherry Vinaigrette" is a good example of this type of salad, as is Ingle and Kramis' (1999), "Oregon Blue Cheese, Bartlett Pear, and Hot Walnut Salad," and Atkinson's (1999), "Pear and Hazelnut Salad with Oregon Blue Cheese."

Orchard fruits shine in desserts more than in any other type of dish they are a part of. These desserts tend to be unpretentious and "homey," what one might expect to find on their grandmother's table. They are baked into fritters, cobblers, crisps, pies, grunts, cakes, tarts, and dumplings, or top short-cakes and flavor ice creams.

Pears and apples make up the bulk of fruit desserts. They are easy to come by and their seasons and storage capacity are long. They include recipes for baked pears (Hibler 1996; Brack and Bell 1988), pear cake (Ingle and Kramis 1999), and pear pie (Brack and Bell 1988; Ingle and Kramis 1999). Poaching is a common technique used in contemporary pear desserts and one that appears to be unique to pears. To give this classic dish a regional twist they are poached in regional red wines such as Oregon Pinot Noir (Casey 1993), or served with blackberry sauce (Brack and Bell 1988).

Northwest regional cookbooks, both early and contemporary, have recipes for America's best-known dessert, apple pie (Brown 1952; Atkinson 1999). Both also include multiple recipes for fresh apple cakes, including "Okanagan Apple Cake with Maple Cream" (Casey 1993), "Captain Whidbey's Apple Cake" (Doerper 1984), 
"Nighthawk Applejack Cake" (Nims and McKean 1996), "Fresh Apple Cake" (Ingle and Kramis 1999), "Apple Cake" (Laughton 1946), as well as "Apple Kuchen" (Laughton 1946). None of these dishes is particularly regional; however, the use of place names in a number of them gives them a regional association. Another dish shared by both an early (Brown 1952) and contemporary cookbook (Ingle and Kramis 1999) is "Apple Grunt," "an old-fashioned dessert of fruit topped with biscuit dough and stewed" (Herbst 1995, 265).

Recipes for more fleeting fruits—cherries, peaches, and plums-are also represented but to a lesser degree. These fruits and their recipes signify summer. Consumers eagerly await the arrival of local cherries, peaches, and plums, and as with other fruits and berries, they are primarily used in cobblers, pies, tarts, and cakes.

\section{Hazelnuts}

Hazelnuts, unlike berries and fruits, are stars of some of the region's most sophisticated desserts, such as "Hazelnut Soufflé with Hazelnut Sauce" (Brack and Bell 1988), "Dark Chocolate Hazelnut Torte" (Taggart and Taggart 1998), and "Hazelnut Cheesecake with a Chocolate Crown" (Brooks 1993). They are also ingredients in many side dishes such as "Hazelnut Rice Pilaf" (Atkinson 1999), "Wild Rice with Apricots, Fennel, and Hazelnuts" (Brooks 1993), and "Oregon Blue Cheese Torte with Hazelnut Pastry" (Skott and McKean 1995), and are frequently used with mushrooms, berries, or orchard fruits. 


\section{Mushrooms}

Mushrooms-chanterelles, morels, shiitakes, and the unassuming white button-flavor much of Northwest cuisine. They stand alone, sautéed in butter or oil (Atkinson 1999) or with leeks and basil (Brooks 1993), float in soups (Brack and Bell 1988) and bisques (Atkinson 1999), or fill raviolis (Sarich 1993), phyllo (Casey 1993), pies (Brown 1952), and omelets (Taggart and Taggart 1998). They also accompany many other foodstuffs including beef and lamb.

Beef and Lamb

"Oregon Blue Cheese Stuffed Flank Steak with Mushroom Sauce" (Sarich 1993), "Tenderloin of Beef with Red Wine, Walnuts, and Oregon Blue Cheese" (Ingle and Kramis 1999), and "Beef Stew With Dark Beer and Sourdough Dumplings" (Pisegna 1990) are recipes that typify how contemporary cookbooks suggest Northwesterners serve beef. These traditional preparations are given a regional flavor with wine, mushrooms, and cheese.

Lamb receives similar regional treatments, from "Medallions of Lamb with Pinot Noir and Hazelnut Sauce" (Ingle and Kramis 1999) to "Grilled Ellensburg Lamb Chops with Morel Sauce" (Sarich 1993). One accompaniment that appears repeatedly is a combination of mint and apples. Callahan (1935) includes a recipe for "Leg of Lamb with Mint Apples," Brack and Bell (1988) feature "Grilled Leg of Lamb with Apple-Mint Chutney," and Casey (1993) describes, "Mint Lamb with Pear Relish." 
Game

Like other meats, duck, pheasant, quail, and venison are served with signature Northwest foodstuffs—fruits, berries, hazelnuts, mushrooms, and wine-to give them a regional flavor. Steamed duck is served with chanterelles (Pisegna 1990), pheasant is baked with morels, peaches, and cream (Hibler 1996), quail is stuffed with barley, prunes, and hazelnuts (Brooks 1993), and venison is served with chestnuts and a gooseberry-cabernet sauce (Pisegna 1990).

\section{$\underline{\text { Seafood }}$}

The number of seafood recipes in regional cookbooks is exhaustive. There are many more seafood recipes than beef, lamb, or game. Crab dishes, especially ones that call for Dungeness crab (a crab that only lives in the Pacific along the coastline of the Pacific Northwest), are the most popular, and mussel dishes the least, particularly in early cookbooks. Most seafood recipes are for dishes or preparations that are not specific to the Northwest. Seafood are fried, sautéed, grilled, poached, baked, steamed, and used in soups or stews.

There are over 15 recipes for mixed seafood stews alone, six of which are for cioppino (Callahan 1935; Brown 1952; Brack and Bell 1988; Hibler 1996; Nims and McKean 1996; Ingle and Kramis 1999), a dish that was created by Italian immigrants in San Francisco (Herbst 1995). Oyster stews and bisques are common as well, particularly ones that also include spinach (Brack and Bell 1988; Brooks 1993; Hibler 1996). And of course, there are chowders, both red and white, for clams (Hibler 1996; 
Taggart and Taggart 1998) and mussels (Brooks 1993; Nims and McKean 1996), dishes that are more closely associated with regions other than the Northwest.

Three of the cookbooks include recipes for an oyster omelette-like dish, "Hangtown Fry" (Brown 1952; Gault 1978; Casey 1993), another dish that is representative of an area outside of the Northwest. It is thought to have originated in Hangtown, now Placerville, California during the Gold Rush (Herbst 1995).

Crab is used in recipes for everything from pasta (Brack and Bell 1988; Casey 1993), to stir-fries (Doerper 1984), won tons (Nims and McKean 1996), bisques (Brown 1952; Doerper 1984; Ingle and Kramis 1999) and crab cakes. Recipes for crab cakes, a dish that is more closely associated with the Eastern seaboard than the Northwest, appear more often than any other crab recipe (Brack and Bell 1988; Brooks 1993; Casey 1993; Sarich 1993; Nims and McKean 1996; Taggart and Taggart 1998; Ingle and Kramis 1999). The use of Dungeness crab, as well as sauces such as pear chutney (Brooks 1993), give this dish a regional flavor.

Shrimp is used more than any other shellfish in Asian influenced recipes featured in both early and contemporary cookbooks. Asian inspired recipes from early cookbooks read like they are from a Cantonese-American restaurant and include "Fried Chinese Shrimps" and "Cantonese Shrimp Balls" (Brown 1952). Contemporary cookbooks show the influence of Thai and Vietnamese cooking in recipes such as "Hood Canal Spot Prawns with Thai Bean Sauce" (Sarich 1993) and "Than's Shrimp and Shredded Cabbage Salad" (Ingle and Kramis 1999). 
In contemporary cookbooks scallops are often used in Italian inspired dishes. They include "Fettuccine with Scallops and Fresh Tomato Sauce" (Brack and Bell 1988), "Seared Sea Scallops with Roasted Red Peppers and Polenta" (Casey 1993), "White Lasagne with Scallops" (Brooks 1993), "Linguine with Scallops and Saffron Cream" (Brooks 1993), and "Scallop Sauté on Soft Polenta with Hazelnut Butter" (Taggart and Taggart 1998).

Fish

Fish recipes, like those for seafood, are many in number and diverse in preparation. Northwesterners have access to many different kinds of fresh fish, both farm raised and wild. There are recipes for trout, steelhead, sturgeon, and salmon, as well saltwater fish such as halibut, black cod or sablefish, lingcod, tuna, and sole.

Of the saltwater fish, halibut recipes are most frequent and range from "Halibut Fish and Chips" (Laughton 1946) to "Roast Garlic Soup with Halibut, Potatoes, and Fresh Corn" (Hibler 1996), to the regionally inspired, "Halibut Breaded with Hazelnuts and Lemon Verbena Sauce" (Pisegna 1990). Other halibut recipes reflect a number of ethnic influences: Japanese in "Kasu Halibut" (Hibler 1996), Norwegian in "Norwegian Fish Pudding" (Laughton 1946), and Italian in "Baked Fresh Halibut with Pesto" (Sarich 1993). There are also Asian inspired recipes for black cod (Nims and McKean 1996), lingcod (Ingle and Kramis 1999), and tuna (Taggart and Taggart 1998). 
Trout, steelhead, and sturgeon recipes frequently include other signature Northwest foodstuffs including hazelnuts, pears, and mushrooms. "McKenzie Creek Trout with Fennel Pear Butter" (Brooks 1993), "Roasted Steelhead with MintHazelnut-Pesto" (Nims and McKean 1996), and "Columbia River Sturgeon with Chanterelles, Sun-Dried Tomatoes and Basil" (Casey 1993) are examples of this. Also common are recipes for smoked trout-they make up one-third of the total number of trout recipes included in contemporary cookbooks.

Of all the fish presented, Pacific salmon (King or Chinook, Silver or Coho, and Sockeye or Red) are held up as something extraordinary and prepared in every conceivable fashion.

\section{Salmon}

Contemporary cookbooks make it clear that Northwest Native American preparations-planked and roasted over a fire, smoked, and wind-dried--are the traditional Northwest way to serve salmon. They include interpretations of these dishes suitable for the home cook that include salmon baked on a store-bought alder plank in the oven, such as "Alder-Planked Sockeye Salmon with Lemon Shallot Sauce" (Ingle and Kramis 1999), or grilled salmon, such as "Grilled Salmon with Hazelnut-Lime Butter" (Brack and Bell 1988) and "Grilled Copper River Salmon with Cucumber Dill Sauce" (Sarich 1993). These methods, baking (or roasting) and grilling (or barbecuing) are the most popular salmon preparations in contemporary 
cookbooks. According to Atkinson, "no dish captures the Northwest style more than grilled salmon" $(1999,39)$.

A staggering number of recipes include smoked salmon. It is used in spreads (Casey 1993; Hibler 1996; Nims and McKean 1996; Ingle and Kramis 1999), scrambled eggs (Brack and Bell 1988; Ingle and Kramis 1999), pasta dishes (Brack and Bell 1988; Atkinson 1999), and quiches (Atkinson 1999), among others. In addition to recipes that describe how to smoke salmon (Gault 1978), a number of recipes advise making or using gravlax or pickled salmon (Gault 1978; Casey 1993; Nims and McKean 1996; Ingle and Kramis 1999). Fresh salmon recipes include hashes (Brack and Bell 1988), salmon patties (Taggart and Taggart 1998), and salads (Hibler 1996).

Early recipes include "Smoked Salmon Pinwheels" (Laughton 1946), "Deviled Salmon" (Laughton 1946), "Salmon Loaf" (Laughton 1946), "Kippered Salmon Fluff" (Callahan 1935), and often call for canned salmon rather than fresh. It is interesting to note that of the three early cookbooks I surveyed, the only one dedicated specifically to the Pacific Northwest, Mary Cullen's Northwest Cook Book (1946), has the most salmon recipes. However, as I mentioned earlier, salmon is treated as an equal among other fish.

As with other fish there are a number of Asian inspired or fusion salmon recipes, including "Salmon Cakes with Ginger Aioli and Sesame Vegetable Slaw" (Casey 1993), "Salmon Belly Tempura" (Nims and McKean 1996), and "Shioyaki Salmon" (Hibler 1996). Regional fish and seafood seem particularly adaptable to 
ethnic food and dishes, particularly cuisines such as Asian that traditionally use a lot of fish and seafood.

\section{Ethnic Influences and Dishes}

All the contemporary regional cookbooks acknowledge the influence different cultural groups have had on cooking in the Pacific Northwest. Even the early cookbooks do this to an extent. Chinese cooking is the prominent ethnic or "foreign" influence in the Sunset All-Western Cook Book, Helen Brown's West Coast Cook Book, and Mary Cullen's Northwest Cook Book. Others mentioned are Mexican, Italian, Japanese, Spanish, Russian, Scandinavian, Yankee (or British), French, and German. Rather than integrating ethnic recipes into the main text they each include chapters titled, "Foreign Foods." Foods that by today's standards are Americanized versions of ethnic or foreign foods rather than authentic ones: chop suey, chow mein, chile con carne, spaghetti and meatballs, and macaroni. References to other ethnic foods such as French and Scandinavian, are not "foreign" enough to warrant inclusion in the chapters on foreign foods. One finds them, and most other recipes attributed to westem European cooking styles (except Italian), sprinkled throughout the other

chapters. A number of recipes in the Sunset All-Western Cook Book have French sounding names such as "Peas a la Madame" (Callahan 1935, 22).

Contemporary cookbooks leave one with the impression that of all the ethnic culinary influences, Asian has had and continues to have the greatest impact on Northwest cuisine. Having said that, it is important to remember that many of the 
recipes we take for granted as "American" are really interpretations of European dishes, dishes that do not seem foreign or ethnic even though their roots lie in other cultures.

The number of Asian influenced or inspired recipes-primarily Chinese, Japanese, Vietnamese, and Thai-is more than double that of all other influences combined. Many combine Northwest foods with traditional preparation techniques and include "Curry Asparagus Soup with Oregon Bay Shrimp" (Sarich 1993), "Chinese Style Deep-Fried Smelts" (Casey 1993), "Dungeness Crab Stuffed Won Tons" (Gault 1978), "Steamed Clams with Sake and Ginger" (Brack and Bell 1988), and "Kimmai's Vietnamese Shrimp and Pork Rolls" (Hibler 1996). Also, it is not uncommon for European based recipes to include Asian ingredients such as ginger, lemongrass, and coconut milk.

Other cultural influences that permeate contemporary cookbooks are Basque and Italian. There are surprisingly few Mexican or other Latin American dishes. Basque recipes tend to not be integrated with regional foodstuffs and include: "Sheepherders Bread" (Casey 1993; Hibler 1996), "Basque Onions in Sour Cream" (Casey 1993), and "Basque Potatoes" (Gault 1978). Italian influence is evident when Northwest foodstuffs are paired with pasta, risotto, or polenta. 


\section{CONCLUSION}

The use of the region's many specialty agricultural products—berries, orchard fruits, hazelnuts, and mushrooms-in meat, game, fish and seafood dishes, as well as salads, are defining aspects of Northwest cuisine, as illustrated by the contemporary cookbooks I surveyed. That early regional cookbooks do not emphasize these foodstuffs to the extent that contemporary ones do suggests that this focus on regional foodstuffs and regional interpretations of national dishes is relatively new. Early cookbooks illustrate that ethnic influences, particularly Asian ones, are not necessarily recent additions to the region's cuisine.

Salmon, more so than any other foodstuff, is the quintessential Northwest food. It is historically significant and has reached iconic status in the Pacific Northwest. The relative absence of salmon in early regional cookbooks, in comparison to its starring role in contemporary ones, echoes how Northwesterners' ideas about salmon have changed in the last fifty or so years. Salmon has gone from being an abundant and rather common foodstuff, to one that is rare, expensive, and indispensable to Northwest cuisine. 


\section{CHAPTER IV}

\section{PORTLAND RESTAURANTS: PURVEYORS OF NORTHWEST REGIONAL CUISINE}

Restaurants play an increasing role in the American diet as people eat outside the home with greater frequency. Although fast food and casual restaurants have seen the most significant rise in visitation, fine dining establishments have received a share of this increase (Mogelonsky 1998). Dining in exclusive restaurants, which in Portland range from neighborhood bistros to traditional white-linen establishments, is no longer limited to special occasions or business dinners. Eating out has become a source of entertainment and a marker of social prestige for an increasing number of Portlanders. The growth of fine dining restaurants in Portland in the 1990s indicates that a greater percentage of Portland's population can afford to-and chooses to-support this type of eatery. The success of these restaurants also suggests that they cater to or reflect the social climate of those who frequent them. As one chef I interviewed suggested, society unconsciously dictates the direction tastes and cooking styles go, and that restaurants are the conscious outlet of these ideas.

Many chefs consider themselves artists and seek to distinguish themselves and their dishes in innovative and creative ways. Yet they need to satisfy the expectations and wishes of their customers who do not always want something new. As one Portland chef described it, his customers are worldly yet crave the familiar. They are 
nostalgic for dishes they may or may not have grown up with, dishes that provide a sense of history and that are linked to a particular place. This leaves chefs with the task of re-inventing familiar dishes or creating historically and regionally inspired ones.

Feeding their patrons is not the only role these chefs play. Today chefs are celebrities and public figures. They publish cookbooks, host cooking shows, teach cooking classes, have slots on local news programs, and write for magazines. They participate in national and international associations such as Chefs Collaborative 2000 and Slow Food, that address social, cultural, and environmental aspects of food production and consumption. In some cases they have become spokespersons or ambassadors for the foods they prepare and the regions they prepare them in. Local chef Ron Paul played this role by hosting a Northwest dinner for President Clinton and other participants of the Northwest Timber Summit in 1993. Paul served venison liver, Oregon gray truffle mousseline, grilled fiddlehead ferns with grilled wild mushrooms, house-smoked sturgeon, Umpqua mussels and oysters, and Columbia River Caviar. His goal was, "to let the foods and wines of the region be the spokespersons for the environment" (Sarasohn 1993, 30).

More recently, the Oregon Tourism Commission and the Portland Oregon Visitors Association ran a marketing campaign featuring Northwest chefs and foodstuffs that included a four-page advertisement in the April 1999 issue of Gourmet magazine. The advertisement attempts to seduce readers by describing the beauty and bounty of the region and by featuring chefs who have made Portland their home. One 
page of the advertisement asks readers if they know what bounty is and then supplies

them with Portland's answer:

Within the urban boundaries of this city called Portland there are beautiful apples and pears from Hood River, berries, cherries, wild huckleberries. Goat and blue cheeses, hazelnuts and fennel. Willamette Valley lamb, Dungeness crab, zucchini from Sauvie Island. There are mushrooms from the Cascades: chanterelles, wild white truffles. Squashes of every imaginable configuration. And we are truly blessed with Pinot Noir and good beer because the fickleness of nature has endowed us with fine grapes, good water, hops and wheat (Oregon Tourism Commission and Portland Oregon Visitors Association 1999).

To enhance this image of bounty the text is overlaid on a close-up photograph of a chanterelle. The advertisement also describes, "the cozy relationship between chef and purveyor" and "the respect most Pacific Northwesterners have for the environment," both of which influence the foods Portland chefs serve (Oregon Tourism Commission and Portland Oregon Visitors Association 1999).

Many of the restaurants featured in this advertisement participated in my study. In both the survey and the interviews, participants addressed and elaborated on ideas put forth in this advertisement, such as the restaurant-farm connection, thus extending their role of spokesperson to informant.

\section{PARTICIPATING RESTAURANTS}

Most of the restaurants that participated in this study are privately owned and chef-driven, meaning chefs design their own menus rather than adhering to a menu set by management or ownership. Many of the restaurants are owned at least in part by their executive chefs. All except two opened for business during the 1990 s and have 
been part of what one chef described as, "a boom in upscale restaurants that have opened up [in Portland] that try to explore local ingredients to their best" (Table IV).

These restaurants are not strictly regional; however, 85 percent say that they prepare dishes representative of the region. They classify their food as "Northwest Regional," "Northwest Seasonal Bistro," "Northwest and World Bistro," and "Seasonal Northwest." Those whose reach is broader describe themselves as "Mediterranean," "American Brasserie with French and Italian Influences," "PanAsian," and as serving "Foods of the Americas." Chefs at many of these restaurants, even those originally from the Pacific Northwest, were trained in classical French and Italian cooking, and began their careers in trend-setting cities such as New York, Chicago, San Francisco, or Los Angeles. Some have studied overseas as well. These influences are evident on the menus of many restaurants, both in preparation style and the use of specific ingredients. Even the restaurants that most closely identify themselves with the region exhibit international and national influences. In fact those influences are often easier to recognize than regional ones.

The most recognizable regional attribute of these restaurants and the dishes they prepare is the use of foodstuffs that are grown, gathered, caught, or produced in the Pacific Northwest, many of which are strongly associated with the region's agricultural and wild landscapes. Some restaurants advertise on their menus and promotional materials that they use local foodstuffs, or refer to regional and place names in the descriptions or names of dishes, such as Fiddleheads Restaurant's 
TABLE IV

\section{PARTICIPATING RESTAURANTS}

\begin{tabular}{|c|c|c|c|c|c|}
\hline RESTAURANT & OPENED & TYPE OF CUISINE $^{7}$ & SURVEY & INTERVIEW & MENU \\
\hline Atwaters & 1983 & Seasonal Pacific Northwest & yes & yes & yes \\
\hline Caprial's Bistro & 1992 & Bistro Style & yes & yes & no \\
\hline Compass Café & 1995 & Northwest \& World Bistro & yes & yes & yes \\
\hline Esplanade & 1986 & $\begin{array}{l}\text { Northwest Regional \& } \\
\text { Mediterranean }\end{array}$ & yes & no & no \\
\hline Fiddleheads & 1995 & $\begin{array}{l}\text { Indigenous Foods of the } \\
\text { Americas }\end{array}$ & yes & yes & yes \\
\hline Higgins & 1994 & $\begin{array}{l}\text { Regional/Local with } \\
\text { Classical Foundation }\end{array}$ & yes & yes & yes \\
\hline Ivy House & 1996 & Northwest Bistro Style & yes & yes & yes \\
\hline Paley's Place & 1995 & Northwest Seasonal Bistro & yes & yes & yes \\
\hline Paragon & 1997 & American Brasserie & yes & yes & yes \\
\hline Pavillion Grill & 1975 & Northwest Cuisine & yes & no & no \\
\hline Saucebox & 1995 & Pan-Asian & yes & yes & no \\
\hline Southpark & 1998 & $\begin{array}{l}\text { Mediterranean Influenced } \\
\text { Seafood }\end{array}$ & yes & yes & yes \\
\hline Wildwood & 1994 & Northwest Inspired & yes & yes & yes \\
\hline Zefiro & $\begin{array}{l}\text { 1990/closed } \\
\text { in early } 2000\end{array}$ & Mediterranean & yes & no & no \\
\hline
\end{tabular}

${ }^{7}$ These descriptions were provided by chefs when asked on the survey to briefly describe the type(s) of cuisine their restaurant serves. 
"Braised Clatskanie Pheasant with Ute Grill Bread." The menu at Higgins Restaurant and Bar carries this further by including a essay outlining the restaurant's philosophy about using locally produced foodstuffs. It concludes by stating:

The cuisine here at "Higgins" is truly rooted in our Northwest soil. We hope our commitment to these principles of ingredients which are local, seasonal, organic and sustainable will nourish your mind and body. Please help by supporting our local organic farmers when you shop for your kitchen. Their fruits and vegetables represent so much more than just good flavor-they are the seeds of our future.

This essay also touches on additional characteristics of Northwest cuisine, as interpreted by Portland area restaurants: a preference for foodstuffs that are not only local but in season and organic as well, and the collaborative role local farmers play by providing these foodstuffs. Like Alice Waters, many Portland chefs believe that promoting the use of local and regional foodstuffs is an economic and social investment in the region, a region that has traditionally been known as an food "Eden." The region's small-scale farmers and purveyors, and the region's cuisine benefit from their association with one another. The region and its identity benefit from this as well. This association promotes the idea that the Pacific Northwest is a region that values its environment and that seeks to preserve its natural and agricultural landscapes.

\section{THE NORTHWEST AS A CUISINE REGION}

Like contemporary cooking literature, chefs and restaurateurs describe the Pacific Northwest as rich, bountiful, lush, and pristine, and reach back to Native 
American, American and European-British, French, Scandinavian, and

German-settlement to draw on cultural influences that have helped shape the region and its cuisine. Chefs recognize that the region's climatic variability, its diverse growing areas, coastline, and rivers enable the region to produce a wide variety of foodstuffs. And like cookbooks, chefs describe the use of regional foodstuffs as the defining aspect of the Northwest's cuisine. Most agree that the region's cuisine is centered in Oregon and Washington. Some include Idaho, Montana, Wyoming, Northern California, British Columbia, and Alaska (Figure 3). ${ }^{8}$

There is a stronger feeling in the restaurant community than in the cooking literature that this cuisine is in its youth. Some chefs do not believe it is a cuisine at all. They argue that the region is too young to have a cuisine and that the region does not have recipes or dishes that have been handed down over time or made the same way for years and years, and without them there cannot be a regional cuisine. According to one chef:

If somebody asked me to name a dish that is a purely Northwestern dish, I don't know if that dish exists. You can perhaps identify Louisiana by saying gumbo and crawfish. You can go to Texas and say chili and that would represent the state. How would represent Oregon and Washington? I don't know. You've got the ingredients that are presented but [not] the dish itself.

These same chefs also argue that the region is not culturally homogenous enough, either historically or at present, to have a regional cuisine. According to one

\footnotetext{
${ }^{8}$ The boundaries of the Pacific Northwest are fuzzy and do not necessarily correspond to the state boundaries delineated on this map; however, chefs defined boundaries by state lines.
} 


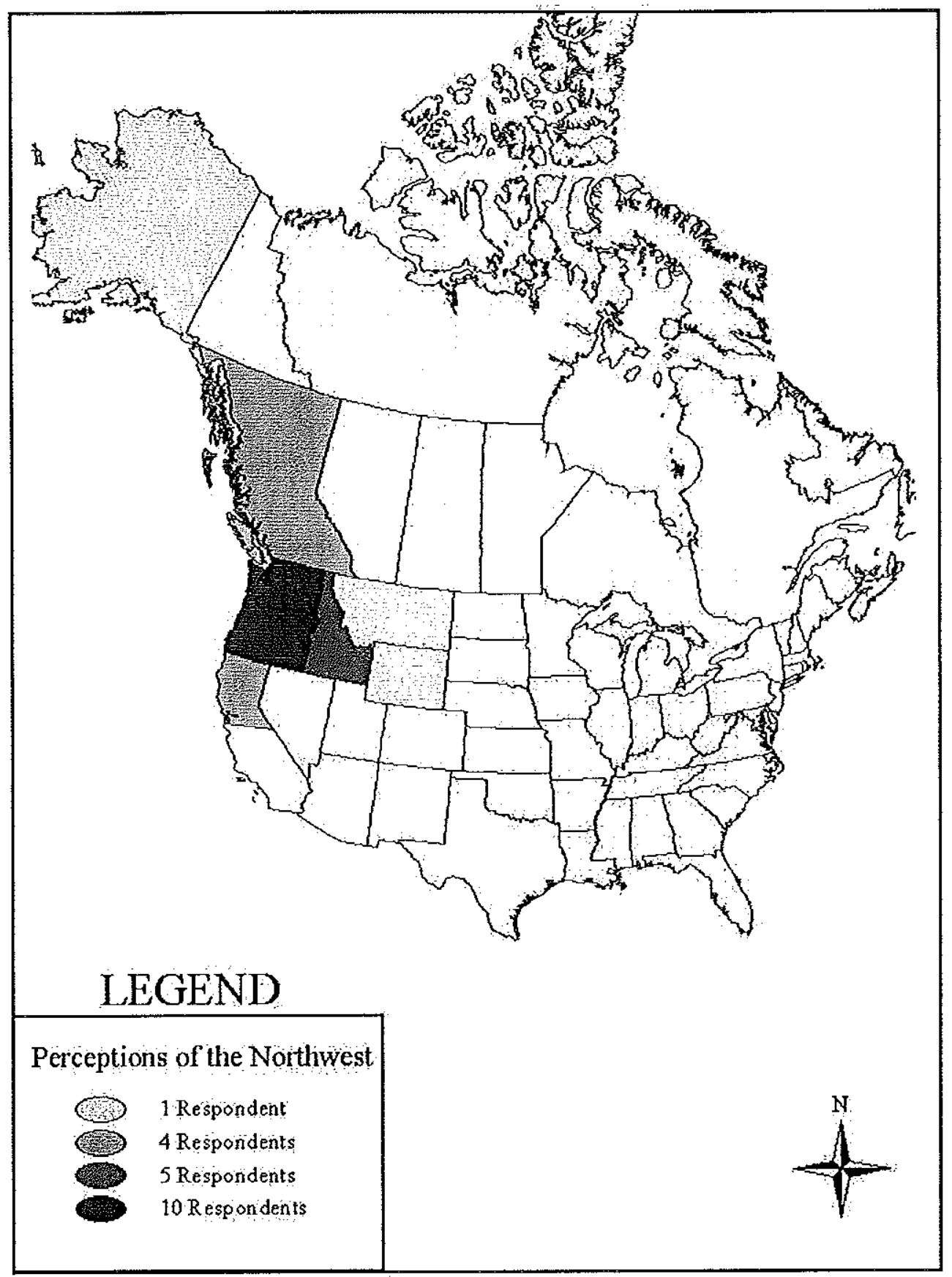

Figure 3: Map of the Pacific Northwest Based on a Compilation of Maps Drawn by Participants 
chef, without a long use of regional foodstuffs by one cultural group or a blending of cultural groups, a distinctive regional cuisine will not develop. Others believe that the dishes chefs are preparing now, as well as ones featured in regional cooking literature, will become the region's cuisine in the future.

Regardless of whether they believe there is a Northwest cuisine or not, most chefs feel that there is a regional style of cooking, similar to that of nouvelle or California cuisine, and agree that a traditional Northwest meal would be based on the inclusion of particular foodstuffs rather than dishes. These foodstuffs are the same ones highlighted by regional cookbooks: berries, hazelnuts, orchard fruits, mushrooms, game, beef, lamb, seafood, and fish, and appear in some combination on dinner menus of most of the restaurants that participated in my study. Many local chefs purchase these foodstuffs from local purveyors, including fishing companies, ranches, foragers, and small-scale farmers, who have created a niche for themselves by catering to the local restaurant community.

\section{THE RESTAURANT-FARM NETWORK}

The restaurant-farm network in the Portland metropolitan area is informal and has been described by one chef as, "a community of individuals who [share] an economic pocket as well sociological and cultural [values]." These values include the belief that locally produced food tastes better and has greater nutritional value. There is also a feeling that foods take on the "taste" of the place where they are grown. This local or regional taste is essential to regional cuisine. Buying from local farmers is an 
environmentally responsible choice because it reduces transportation distance and in many cases these farmers choose to grow organically. By purchasing local produce restaurants - and by extension their customers - are feeding the region's agricultural economy and preserving a traditional way of life in the region.

Many of these farmers also sell their foodstuffs at Portland area farmers markets or belong to the Community Supported Agriculture (CSA) network, selling produce to people who buy an annual subscription. Most are no more than a few acres in size. Many operate year-round, particularly those that grow greens. Like the restaurants in my survey, most have established their businesses in the last ten years. Restaurants that wanted to buy from local farmers prior to this time had fewer sources to choose from.

One of the oldest and best-known regional restaurant farmers is George Weppler. For more than 15 years Weppler has been growing a variety of produce year-round on his 5-acre farm near Brownsville, 100 miles south of Portland. He currently grows 250 kinds of vegetables including 50 types of lettuce. Many Portland area restaurants buy from him and feature "Weppler" greens on their menus. Weppler's farm is more commercial than most of his colleagues, although he likes to describe his farm as more garden-like than farm-like. He does not limit his distribution to the Pacific Northwest and grosses more than $\$ 300,000$ a year (McQuillen 1998).

Unlike Weppler's Farm, Singing Pig Farms limits its distribution to Portlandarea restaurants. What began as a small plot of salad greens in owner Steve Rogers' 
Southeast Portland backyard ten years ago has expanded to include an acre plot near Reed College. He grows a variety of vegetables including turnips, beets, squash, tomatoes, eggplants, shallots, and fennel (Machado 1999).

Most of the chefs I interviewed purchase a significant percentage of their produce from farmers such as Steve Rogers and George Weppler. During the growing season 50 percent buy from between two and five farmers, 14 percent from between six and ten, and 36 percent from more than ten. What they cannot get from local farmers they try to get from distributors who carry local produce. In the off-season most have to supplement what they can get locally with out-of-state produce. Salad greens, root vegetables, orchard fruits, berries, and herbs are the foodstuffs chefs commonly purchase from local farmers. Occasionally chefs are given some say in what is planted, and some forage or have their own gardens for their restaurants, thus giving them greater choice when planning their menus.

\section{MENU ANALYSIS}

Even though all the menus I surveyed feature regional and local foodstuffs, their dishes are not strictly regional. Many of the seafood, fish, meat, game, and fowl dishes would be equally at home on menus at similar restaurants throughout the United States. Oysters served on the half shell are a good example of this. Oysters, even though they are a part of the Northwest's palate of regional foodstuffs, are not exclusive to the region. 
These menus also reflect the national trend of combining flavors and techniques from different cuisines while using regional ingredients. Some dishes simply substitute regional ingredients for traditional ones, such as salmon for pork in wontons, whereas others represent a fusion of American, European, Latin American, and Asian preparation techniques and flavorings. Atwaters' Asian-French combination, "Hamachi Style Ahi Tuna with Sautéed Julienne Vegetables, Sushi Rice, and Citrus Vinaigrette," and Higgins' Italian-Latin American dish combing risotto with salsa verde are typical of fusion cooking.

Other cultural influences are evident as well. French preparations such as "au Poivre" (with pepper) or sauces like mignonette and aioli are common. Pasta and risotto are often used in vegetarian dishes and are frequently served with mushrooms. Ginger and other spices are used to give dishes an Asian flavor and chilies bring a taste of Latin America to Northwest dishes.

Despite the fact that most chefs I interviewed acknowledged Native American influences on the region's cooking, particularly the use of salmon, few Native American influenced dishes appear on menus. Fiddleheads Restaurant, which focuses on indigenous foods of the Americas, is the only restaurant that regularly features dishes inspired by Northwest Native American cooking. Their menu did not include salmon at the time of my research; however, they occasionally serve salmon that has been cooked on an alder plank, a traditional Northwest Native American preparation that some chefs argue is the Northwest's signature dish. 


\section{Regional Dishes}

When two or more regional foodstuffs are used in combination dishes begin to take on regional significance. As in cookbooks this is most evident when meat, game, or fowl is served with fruit, mushrooms, or hazelnuts (Table V). Absent from these menus, however, is the extensive use of berries with meat or fowl. This may be because the menus in my analysis are from early spring, too early in the season for fresh berries.

TABLE V

NORTHWEST COMBINATIONS

\begin{tabular}{|l|l|}
\hline DISH & RESTAURANT \\
\hline $\begin{array}{l}\text { Free Range Chicken with Morels, Onions, Bacon, } \\
\text { and Red Wine }\end{array}$ & Atwaters \\
\hline $\begin{array}{l}\text { Truffle Infused Smoked Beef Tenderloin with } \\
\text { Forester Potatoes and Pinot Noir }\end{array}$ & Atwaters \\
\hline Hazelnut Crusted Chicken with Wild Mushrooms & Compass Café \\
\hline $\begin{array}{l}\text { Braised Oregon Buffalo with Wild Boar Bacon, } \\
\text { Mild Chilies, Root Vegetables, and Wild } \\
\text { Mushrooms }\end{array}$ & Fiddleheads \\
\hline $\begin{array}{l}\text { County-Style Terrine of Venison, Chicken, and } \\
\text { Pork with Dried Cherries and a Roasted Garlic } \\
\text { Mustard }\end{array}$ & Higgins \\
\hline $\begin{array}{l}\text { Roast Pork Loin Medallions with Oregon Blueberry } \\
\text { Glaze and Mashed Red Potatoes }\end{array}$ & Ivy House \\
\hline $\begin{array}{l}\text { Maple Glazed Chicken with Bacon Lardons, } \\
\text { Granny Smith Apples, and Caramelized Onions }\end{array}$ & Paley's Place \\
\hline $\begin{array}{l}\text { Sautéed Breast of Muscovy Duck with Herb } \\
\text { Spatzle, Honey Glazed Pears, and Rhubarb Mustard }\end{array}$ & Paley's Place \\
\hline $\begin{array}{l}\text { Boneless Pork Chop Roasted with Pear, Bourbon } \\
\text { Corn Gratin, and Braised Mustard Greens }\end{array}$ & Paragon \\
\hline
\end{tabular}


A handful of chefs jokingly suggested that a mixed green salad with hazelnuts (or some other nut), pears or apples, topped with blue cheese or chèvre, and dressed with a vinaigrette is "the" Northwest dish (Table VI). That some variation of this salad appears on almost every menu and is mentioned in many cookbooks suggests that it may very well be one of the Northwest's signature dishes.

\section{TABLE VI}

NORTHWEST SALADS

\begin{tabular}{|l|l|}
\hline SALAD & RESTAURANT \\
\hline $\begin{array}{l}\text { Wilted Spinach Salad with Warm Bacon and } \\
\text { Balsamic Vinaigrette, Spiced Hazelnuts, Pears, and } \\
\text { Chèvre }\end{array}$ & Compass Café \\
\hline $\begin{array}{l}\text { Fiddlehead's Calapooya Style Salad-tender new } \\
\text { greens, lettuces, and apples with Oregon bleu } \\
\text { cheese, toasted pine nuts, and maple vinaigrette }\end{array}$ & Fiddleheads \\
\hline $\begin{array}{l}\text { Salad of Gathered Spring Greens, Toasted } \\
\text { Hazelnuts, and Herb Vinaigrette }\end{array}$ & Higgins \\
\hline $\begin{array}{l}\text { Tender Green's Watercress Salad with Oregon Blue } \\
\text { Cheese, Caramelized Pears, and Toasted Walnuts }\end{array}$ & Paley's Place \\
\hline $\begin{array}{l}\text { Baby Spinach with Roasted Pear, Chèvre, } \\
\text { Hazelnuts, and Bacon Sherry Vinaigrette }\end{array}$ & Paragon \\
\hline $\begin{array}{l}\text { Weppler Organic Greens and Candied Walnuts } \\
\text { with Aged Spanish Goat Cheese or Cabrales Blue } \\
\text { Cheese }\end{array}$ & Southpark \\
\hline $\begin{array}{l}\text { Seasonal Greens with Toasted Hazelnuts, Blue } \\
\text { Cheese, and Balsamic Currants }\end{array}$ & Wildwood \\
\hline
\end{tabular}




\section{Salmon Dishes}

When asked what foodstuff they most associate with the Pacific Northwest all the chefs I interviewed said salmon. According to one local chef:

If I had to pick just one ingredient as an icon, I would pick salmon. It was used by Northwest Native American people and has been part of the [Northwest's] culture and foodstuffs for hundreds of years .... [it] shows the way Northwest people have lived their lives-it shows our love of the outdoors and our respect.

Another chef described salmon as intimately linked to the region's landscape because it returns to its place of birth to complete its lifecycle.

Most chefs serve salmon when it is available fresh because they believe their customers expect it. Dishes range from simple to elaborate, and some include other regional foodstuffs or ethnic influences (Table VII). They prefer to serve "wild"9 Pacific salmon (Chinook, King, or Coho) over farm-raised or Atlantic salmon, thus limiting how often they are able to include it on their menus. However, not every chef is enthusiastic about salmon. A few described it as boring, tiresome, or ordinary, and serve it out of a feeling of obligation to their patrons. Even those who enthusiastically serve it do so with trepidation and express concern over declining wild runs. Many try to mitigate this environmental concern by purchasing salmon caught in Alaskan waters where runs are healthier.

9 "Wild" is used to distinguish caught salmon from farm-raised even though the salmon chefs and restaurants refer to is hatchery-bred rather than wild. 
TABLE VII

SALMON DISHES

\begin{tabular}{|l|l|}
\hline DISH & RESTAURANT \\
\hline $\begin{array}{l}\text { Atwaters' Flat Bread with Smoked Salmon Dill } \\
\text { Crème Fraîche and Shaved Fennel Salad }\end{array}$ & Atwaters \\
\hline $\begin{array}{l}\text { Grilled Local King Salmon with Hazelnut } \\
\text { Fingerling Potato Salad and Sorrel }\end{array}$ & Atwaters \\
\hline $\begin{array}{l}\text { House Smoked Salmon Wontons with Honey } \\
\text { Ginger Sauce }\end{array}$ & Compass Café \\
\hline $\begin{array}{l}\text { Salmon and Wild Rice Quesadilla with Black } \\
\text { Beans and Cilantro Salsa }\end{array}$ & Ivy House \\
\hline $\begin{array}{l}\text { Baked Chinook Salmon with Toasted Hazelnut } \\
\text { Crust and Apple Cider Beurre Blanc }\end{array}$ & Ivy House \\
\hline $\begin{array}{l}\text { Grilled Cumin Crusted Salmon with Salad of Local } \\
\text { Cress, Oil Cured Olives, and Blood Oranges }\end{array}$ & Southpark \\
\hline $\begin{array}{l}\text { Oregon Salmon with New Potatoes, Sugar Peas, } \\
\text { Sunchokes, and Bacon, Sweet Onion Vinaigrette }\end{array}$ & Wildwood \\
\hline $\begin{array}{l}\text { Housed Cured Salmon with Crème Fraîche, Pickled } \\
\text { Onions, Capers, and Poppyseed Crackers }\end{array}$ & Wildwood \\
\hline
\end{tabular}

\section{$\underline{\text { Regional Beverages }}$}

To accompany these dishes, many restaurants offer a selection of regional wines and beers. More than half the restaurants I surveyed have beer lists that are more than 75 percent regional and wine lists that are 43 percent regional. Many chefs suggested that these numbers may increase if the microbrew trend remains steady, and as the region's wine industry continues to develop. Again, the desire is to support regional purveyors. One chef suggested that foods that grow well together taste good when served with one another, and by extension, wine and beer produced from local grapes and hops compliments regional foodstuffs. 


\section{CONCLUSION}

The use of regional foodstuffs - particularly when used in combination with one another-distinguish what restaurants define as Pacific Northwest cuisine. This core - the use of regional foodstuffs - is also what characterizes the Northwest cuisine described by contemporary regional cookbooks. The use of these foodstuffs is a matter of taste as well as an attempt to support the region's economy. As chefs work with local farmers and purveyors, they forge social and cultural links within the region and help publicize the idea that the use of local and regional foodstuffs is central to the Northwest's cuisine or its development as a cuisine region. Because of their association with the region's agricultural history and in some cases its cultural history, regional foodstuffs and the dishes they are used in, help satisfy what some chefs have described as a growing hunger for a sense of place or regional identity among their patrons. 


\section{CHAPTER V}

\section{CONCLUDING COMMENTS}

According to Yi-Fu Tuan, "The more Americans participate in, and indeed lead the world in globalism, the more they yearn for locality, tradition, roots" (Tuan $1996,104)$. One way people can fulfill this yearning is by identifying with a regional cuisine, which provides a connection to place and a sense of uniqueness in a relatively homogenized nation and an increasingly global world, thus filling the need to belong somewhere and to distinguish oneself from others. Typically, regional cuisines are described as "a distinctive combination of history, culture, and ingredients that reflects the definitive taste of a place" (McNichol 1991, FD1). This "taste" is usually reflected in dishes that are representative of the cuisine and that are recognizable not only to those within the region but by outsiders as well.

\section{INVENTING NORTHWEST CUISINE}

In the Northwest professional cooks and cookbook authors are helping shape a regional cuisine that is more a product of contemporary sentiment than the traditional or everyday eating habits of residents within the region, characteristics commonly associated with regional cuisines. As part of the new American cuisine movement, Northwest cuisine follows standards set by California cuisine and French nouvelle cuisine, and leading culinary figures such as Alice Waters, that include an emphasis on 
the use of seasonal and local foodstuffs, the incorporation of ethnic influences, and the (re)creation of regional dishes.

The perceived bounty of the Northwest lent itself to the development and promotion of this type of regional cuisine. Northwest cuisine is based on the use of foodstuffs that are emblematic of the region's foodscape, as well as a selective interpretation of foods associated with the region's past. The past these foodstuffs are associated with is idealized and based on the same "Eden" metaphor that brought many settlers to the region during the mid-nineteenth century. In an article for Sunset magazine that describes the "pioneers" of contemporary Northwest cuisine, food writer Schuyler Ingle illustrates this connection between the region's history, foodscape, and contemporary cuisine:

Each year the Pacific Northwest's Native Americans celebrate the coming of First Salmon-chosen symbol of all the fat, hook-nosed chinook salmon that arrive at the mouth of the Columbia River. First Salmon's return is the signal that winter has ended and spring returned to shake off the wet skies the color of cutlery. It has always been this way in the Pacific Northwest. Good food floods the region-stone fruits and berries, greens and root vegetables, new potatoes stolen from volcanic soil, game birds and venison, lamb and pork and beef, wild mushrooms, and the abundance of the sea-it's like a table set for a feast (Ingle 1997, 84).

Northwest cuisine is unlike traditional American regional cuisines such as Southern, that have evolved out of a convergence of different cultures in a particular place and historical context (Edge 1999; Ward 2000). Although Northwest cuisine calls attention to the cultural contributions of those who have settled in the region by serving ethnic or culturally associated dishes alongside regionally inspired ones, or by 
using regional foodstuffs in the preparation of ethnic dishes, these dishes and influences are secondary to regional foodstuffs themselves. Additionally, these ethnic influences are contemporary, such as Pan-Asian, not historic.

Whereas the South has a group of dishes associated with it, including corn based dishes, pork, and vegetables such as collard greens and okra, the Northwest does not. This may be attributed to the Northwest's relative youth in comparison to the South, and the fact that most European-Americans who settled in the region sought, and were able to recreate, dishes from the places they had come from. Despite the fact that Northwest cuisine is relatively young and based on selected regional characteristics and idealized notions about the region's history and foodways, it helps satisfy a need for identity by creating a sense of distinctiveness.

\section{CREATING DISTINCTIVENESS}

This distinctiveness rests on the use of signature regional foodstuffs-berries, orchard fruits, hazelnuts, mushrooms, game, beef, lamb, seafood, and fish-and in some cases, the ways in which they are plated together. However, foodstuffs that are grown in great quantity in the region-potatoes, wheat, and lentils—are not necessarily recognized as part of the signature or specialty foods that make this regional cuisine distinctive. Cookbooks and chefs emphasize an implied relationship between regional foodstuffs and the region in general. These foodstuffs, both cultivated and wild, are linked to the historic and contemporary foodscapes of the region. They are the physical, as well as symbolic manifestations, of a region that is 
Eden-like in its bounty, and provide a point of integration for the many culinary influences in the region, both historically and today. That these same foodstuffs are often celebrated in regional events such as the annual Mount Hood Salmon and Mushroom Festival and the Newport Seafood and Wine Festival, further illustrate their relationship to the region's sense of identity.

By stressing the importance of using locally grown foodstuffs, cookbooks and restaurants establish a link between the physical landscape of the Northwest, its cuisine, and the people who live there. Contemporary cookbooks further this link by including descriptions of the physical geography of the region, as well as its cultural history. They evoke a sense of place by using photographs and other illustrations, including ones of people picking berries or catching salmon, to enhance the idea that these signature foodstuffs are intimately linked to life in the Northwest. Readers are left with the impression that the Pacific Northwest is an utopian landscape where the pastoral and the wild coexist, and where food falls from the tree or jumps from the water on to one's plate. Restaurants also enhance the link between the physical landscape and regional cuisine by establishing relationships with local farmers and by referring to place names on their menus, indicating that the dishes they serve are close to the source. Implied is the idea that one cannot have a truly regional cuisine unless one uses foods grown in the soil or waters of that region. Historically this was true because one had no choice; however, in this time of mass transportation, this concept has become a self-conscious cornerstone of new American regional cuisines. 
Although Northwest cuisine's emphasis is on the use of particular foodstuffs rather than dishes, there are a few combinations of foodstuffs or the beginnings of regional dishes that appear repeatedly on restaurant menus and in contemporary cookbooks. The frequent occurrence of salads made with mixed greens and other regional foodstuffs such as hazelnuts, pears, or local cheese on restaurant menus, as well as the number of similar salad recipes in contemporary cookbooks suggests, that this comes close to being a regional dish. Dishes that combine meat, fowl, game, or fish with berries, orchard fruits, or other specialty foodstuffs such as hazelnuts and mushrooms also come close. They appear frequently on restaurant menus as well as in contemporary cookbooks.

Despite their association with region's sense of identity these dishes are not necessarily prepared and consumed with regularity in the home, nor do we know whether these dishes will persist as signatures for Northwest cuisine or be replaced by new interpretations or constructions of regional cuisine. Their expense, the limited availability of some of the foodstuffs, and the time and confidence required to prepare them, make them more like special occasion dishes than everyday ones. To purchase them in a restaurant is also costly. Most dishes (main course) are priced between $\$ 15.00$ and $\$ 25.00$ per plate, prices which exclude many from purchasing them. The way in which these foodstuffs and dishes are presented and Northwest cuisine is constructed, may have more resonance with the wealthy or outsiders. Other sectors of society certainly eat these same foodstuffs and similar the dishes; however, they may 
do so without consciously associating them with the region and the region's cuisine in the way regional cookbooks and restaurants do. ${ }^{10}$

Both chefs and contemporary cookbooks make it clear that of all the foods and dishes associated with Northwest cuisine, salmon and salmon dishes are the most significant. Salmon is both a signature food and a regional icon.

\section{SALMON AS ICON}

As an icon salmon represents the Pacific Northwest and the values or ideals Northwesterners hold. Although closely associated with Native American cultures in the Northwest, the general populace has adopted the salmon as their icon as well. There is no shortage of descriptions of the role salmon plays in literature and among food writers and chefs. In an essay titled, "Salmon and the Northwest," Roy Hemmingway, a salmon advisor to Oregon's governor, writes:

Salmon are emblematic of the role of natural forces in the lives of Pacific Northwesterners. To have this spectacular wild creature in our midst means we can maintain the connection to the wild that is within us. Take salmon away, and Pacific Northwesterners lose claim to being able to live within a natural environment $(1997 / 1998,10)$.

He concludes by stating that, "The salmon is at the heart of the Pacific Northwest wild heritage. If we let the wild salmon slide into extinction, something of the unique spiritual quality of this landscape will go with them" $(1997 / 1998,17)$.

${ }^{10}$ Burgerville, a Northwest fast food chain, is an exception to this. Like many restaurants in my study they "consciously strive to use local providers and products" (Burgerville 1998). They serve hamburgers made from northwest beef and that are served on buns made from Franz Bakery in Portland. Cheeseburgers are topped with Tillamook cheese. They also serve seasonal foods such as strawberry shortcake made from berries grown in the region and onion rings made from Walla Walla Sweets. 
Journalist Timothy Egan, in his portrait of the region, The Good Rain (1991), describes the Northwest as "wherever the salmon can get to" (p. 22), and salmon as "the life source of the area" (p. 22). He suggests that, "In the Northwest, a river without salmon is a body without a soul" (p. 182). Likewise, in an essay deconstructing the iconization of salmon by Northwesterners, historian John Findlay argues:

As icons, the fish [salmon] convey a variety of messages. They stand, for instance, for the relative abundance of natural resources long associated with the Pacific Northwest, and they represent a concern about the environment that unifies diverse peoples who have long fought over regional resources. As fish migrate across the Cascade Range, which divides the Northwest in half, they are a symbol shared by eastern and western subregions-two parts of the Pacific Northwest that have often not agreed. Additionally, sanctification of salmon serves to mask old grievances between Indians and non-Indians, with the latter now posing as "Indian-like" in their newfound appreciation of "the land" and its resources $(1997,40)$.

In an article titled, "Pretty in Pink: On a $20^{\text {th }}$ Century Plate, a Salmon is the Postcard for the Northwest," Oregonian writer David Sarasohn states that, "salmon carries all the history [of the region]," and that, "it's not exactly true that without salmon nobody would have heard of Oregon, but they've been a pretty effective advertisement" (1999, AE14). He concludes that for most of the twentieth century, "the wild, wide-ranging salmon has represented not only the diet but also the spirit of the area" (Sarasohn 1999, AE14).

The chefs I interviewed share these sentiments. One described salmon as "a timeless symbol of the region," and another, "a lifeway for regional residents." All the contemporary Northwest cookbooks I surveyed hold up salmon as the embodiment 
of all that is Northwestern, and include numerous recipes, some of which are contemporary translations of "traditional" Native American preparations.

Despite these glowing descriptions and the feeling they express that salmon has always been a critical part of the region's identity, some have suggested that salmon is a contemporary icon and that its association with the region has grown as wild salmon

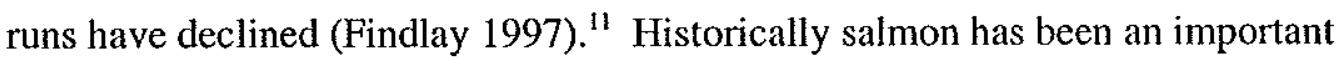
economic commodity in the Northwest; however, as a commodity it was treated with less reverence than it has as an icon for the region. As a commodity salmon was a resource to be exploited and as an icon it is a resource to be preserved.

Early Northwest cookbooks reflect the temporal quality of this icon. They have significantly fewer salmon recipes than contemporary ones and suggest that salmon is nothing more than a fish among other fish. Additionally, studies of historical foodways in the Northwest indicate that salmon was not a preferred foodstuff of early settlers. They often ate it because they had to rather than because it was what they wanted to eat (Williams 1996; Findlay 1997).

Cookbook authors and chefs also neglect to address that salmon is in a sense a contested icon. The water used to irrigate many of the agricultural foodstuffs linked to Northwest cuisine is drawn from rivers in the region, removing much needed water from salmon habitat. And despite acknowledging that salmon runs in the Northwest need protecting, most insist that the salmon Northwesterners eat should be caught

\footnotetext{
${ }^{11}$ In 1999, the National Marine Fisheries Service granted nine Northwest salmon runs federal protection (Starke 1999). Public spending in effort to preserve and increase salmon runs in the Northwest is expected to reach nearly $\$ 1$ billion in the year 2000 (Barnett 1999).
} 
Pacific salmon (mistakenly referred to as "wild" salmon on many menus) rather than farm raised or Atlantic salmon. Cookbook authors and chefs attempt to mediate this tension by relying on salmon from Alaskan fisheries, thus linking Alaska to the Northwest even though it is removed from the region's core (Oregon and Washington).

\section{NORTHWEST CUISINE AND IDENTITY}

If salmon is the icon or metaphor for the region, then food (or cuisine) is a narrative by which to read or understand the Northwest. The creation of contemporary regional cuisine in the Northwest reflects a region that is home to many newcomers and that shares a sense of identity based on physical aspects of the region (foodstuffs) rather than cultural (dishes). By emphasizing the use of regional foodstuffs rather than a shared culinary history, Northwest cuisine embraces new residents from diverse backgrounds as well as "natives." To be a Northwesterner all one needs to do is eat the region's foods. One literally consumes "place" by eating locally grown foodstuffs and symbolically, by consciously associating those foodstuffs with the region, its history, and its Eden-like bounty. 


\section{REFERENCES CITED}

Arreola, D. 1983. "Mexican Restaurants in Tucson." Joumal of Cultural Geography 3(2): 108-114.

Atkinson, G. 1999. The Northwest Essentials Cookbook: Cooking with the Ingredients that Define a Regional Cuisine. Seattle, Washington: Sasquatch Books.

Barnett, J. 1999. "Bureaucracy for Salmon is Closing in on $\$ 1$ Billion." The Oregonian, 28 June, sec. A, p. 1.

Beitiks, E. 1999. "Hometown Cooking: Dissecting Bay's Gift to the Nation's Cuisine." The San Francisco Examiner, 30 Dec., sec. A, p. 1.

Bell, D. and G. Valentine. 1997. Consuming Geographies: We Are Where We Eat. London and New York: Routledge.

Brack, F. and T. Bell. 1988. Tastes of the Pacific Northwest: Traditional and Innovative Recipes from America's Newest Regional Cuisine. New York: Doubleday.

Brenner, L. 1999. American Appetite: The Coming of Age of a Cuisine. New York: Bard, Avon Books.

Brooks, K. 1993. Oregon's Cuisine of the Rain: From Lush Farm Foods to Regional Recipes. Reading, Massachusetts: Addison-Wesley Publishing Company.

Brown, D. 1970. American Cooking: The Northwest. New York: Time Life Books.

Brown, H. 1952. Helen Brown's West Coast Cook Book. Boston: Little, Brown, and Company.

Burgerville. 1998. Burgerville Home Page [web site]; available from http://www.burgerville.com; accessed on 8 June 2000.

Burgess, J. 1994. "Filming the Fens: A Visual Interpretation of Regional Character." In Re-Reading Cultural Geography, edited by K. Foote, P. Hugill, K. Mathewson, and J. Smith, 297-312. Austin, Texas: University of Texas Press. 
Callahan, G. 1935. Sunset All-Western Cook Book, $2^{\text {nd }}$ edition. San Francisco: Lane Publishing Company.

Cardivell, J. 1906. "The First Fruits of the Land: A Brief History of Early Horticulture in Oregon." Oregon Historical Quarterly 7(1): 28-51.

Casey, K., ed. 1993. Pacific Northwest the Beautiful Cookbook: Authentic Recipes from the Pacific Northwest. San Francisco: Collins Publishers.

Center for Population Research and Census. 1994. Population Estimates for Oregon, July 1, 1994, Summary. Portland, Oregon: Center for Population Research and Census, Portland State University.

De Wit, C. 1998. "Food-Place Associations on American Product Labels." In The Taste of American Place, paperback edition, edited by B. Shortridge and J. Shortridge, 101-110. Lanham, Maryland: Rowman and Littlefield Publishers, Inc.

Dicken, S. and E. Dicken. 1979. The Making of Oregon: A Study in Historical Geography. Portland, Oregon: Oregon Historical Society.

Doerper, J. 1984. Eating Well: A Guide to Foods of the Pacific Northwest. Seattle, Washington: Pacific Search Press.

Edge, J., ed. 1999. A Gracious Plenty: Recipes and Recollections from the American South. New York: G. P. Putnam and Sons.

Egan, T. 1991 The Good Rain: Across Time and Terrain in the Pacific Northwest, paperback edition. New York: Vintage Departures. Original edition, New York: Alfred A. Knopf, 1990.

Findlay, J. 1997. "A Fishy Proposition: Regional Identity in the Pacific Northwest." In Many Wests: Place, Culture, and Regional Identity, edited by D. Wrobel and M. Steiner, 37-70. Lawrence, Kansas: University Press of Kansas.

Flack, W. 1997. "American Microbrews and Neolocalism: 'Ale-ing' for a Sense of Place." Journal of Cultural Geography, 16(2): 37-53.

Frenkel, S. 1998. "A Pound of Kenya, Please or a Single Short Skinny Mocha." In The Taste of American Place: A Reader on Regional and Ethnic Foods, paperback edition, edited by B. Shortridge and J. Shortridge, 57-63. Lanham, Maryland: Rowman and Littlefield Publishers, Inc. 
Fussell, B. 1997. I Hear America Cooking: The Cooks and Recipes of American Regional Cuisine, paperback edition. New York: Penguin Books. Original edition, New York: Viking Penguin Inc., 1986.

Gault, L. 1978. The Northwest Cookbook: Living with Abundance in the Pacific Northwest. New York: Quick Fox.

Grigg, D. 1995. "The Geography of Food Consumption: A Review." Progress in Human Geography 19(3): 338-354.

Gutierrez, C. 1992. Cajun Foodways. Jackson, Mississippi: University Press of Mississippi.

Hemmingway, R. 1997/1998. "Salmon and the Northwest." Open Spaces, Winter: 617.

Herbst, S. 1995. The New Food Lover's Companion. Hauppauge, New York: Barron's Educational Series.

Hibler, J. 1996. Dungeness Crabs and Blackberry Cobblers: The Northwest Heritage Cookbook, paperback edition. New York: Alfred A. Knopf. Original edition, New York: Alfred A. Knopf, 1991.

Ingle, S. 1997. "O Pioneers." Sunset (Northwest Edition), August: 84-95.

Ingle, S. and S. Kramis. 1999. Northwest Bounty: A Cookbook Celebrating the Extraordinary Foods of the Pacific Northwest, revised edition. Seattle, Washington: Sasquatch Books. Original edition, New York: Simon and Schuster, 1988.

Kaplan, A., Hoover, M. and W. Moore. 1998. "Introduction: On Ethnic Foodways." In The Taste of American Place: A Reader on Regional and Ethnic Foods, paperback edition, edited by B. Shortridge and J. Shortridge, 121-133. Lanham, Maryland: Rowman and Littlefield Publishers, Inc.

Kelly, J. 1998. "Loco Moco: A Folk Dish in the Making." In The Taste of American Place: A Reader on Regional and Ethnic Foods, paperback edition, edited by B. Shortridge and J. Shortridge, 39-43. Lanham, Maryland: Rowman and Littlefield Publishers, Inc.

Korn, V., ed. 1999. 1998-1999 Oregon Agriculture and Fisheries Statistics. Salem, Oregon: Oregon Department of Agriculture and U.S. Department of Agriculture. 
Kovacik, C. 1998. "Eating Out in South Carolina's Cities: The Last Fifty Years." In The Taste of American Place: A Reader on Regional and Ethnic Foods, paperback edition, edited by B. Shortridge and J. Shortridge, 187-199. Lanham, Maryland: Rowman and Littlefield Publishers, Inc.

Laudan, R. 1999. "A World of Inauthentic Cuisine." In Cultural and Historical Aspects of Foods, Yesterday, Today, and Tomorrow: Proceedings of the Conference in Corvallis, Oregon, April 9-11, 1999, by the Department of Nutrition and Food Management, College of Home Economics and Education, Oregon State University, 136-145. Corvallis, Oregon: Oregon State University.

Laughton, C., ed. 1946. Mary Cullen's Northwest Cook Book. Portland, Oregon: Binfords and Mort Publishers.

Lewis, P. 1990. "The Making of Vernacular Taste: The Case of Stunset and Southern Living." In The Vernacular Garden, edited by John Dixon Hunt and Joachim Wolschke-Bulmahn, 107-136. Washington, D.C.: Dumbarton Oaks .

Limerick, P. 1996. "Region and Reason." In All Over the Map: Rethinking American Regions, edited by E. Ayers, P. Limerick, S. Nissenbaum, and P. Onuf, 83-104. Baltimore and London: The Johns Hopkins University Press.

Lippard, L. 1997. The Lure of the Local: Sense of Place in a Multicentered Society, paperback edition. New York: The New Press.

Machado, E. 1999. "Food Faces: Steve Rogers, 43, Organic Greens Provider, Singing Pig Farms." The Oregonian, Diner, A\& E's 1999 Restaurant Guide, April 16, 1999, p. 7.

McNichol, B. 1991. "Doin' the Dahlia: Tom Douglas Cooks in the Real World Where the Mariners Lose and People Love Crab Cakes." The Oregonian, 28 May, sec. FD, p. 1.

McQuillen, J. 1998. "Greengrocer to the Nation." Willamette Week's 100 Best Restaurants in Portland, 1998-1999, p. 21.

Maryles, D. and D. Donahue, eds. 1999. "Cookbooks: Who's Minding the Stove." Publishers Weekly, 26 July [magazine on-line]; available from http://www.publishersweekly.com/articles/19990726_79373.asp; accessed on 27 March 2000.

Massey, D. 1993. "Questions of Locality." Geography 78(1): 142-149. 
Matzke, G. 1993. "Population." In Atlas of the Pacific Northwest, $8^{\text {th }}$ edition, edited by P. Jackson and A. Kimerling, 18-24. Corvallis, Oregon: Oregon State University Press.

Milbauer, J. 1998. "The Geography of Food in Eastern Oklahoma: A Small Restaurant Study." In The Taste of American Place: A Reader on Regional and Ethnic Foods, paperback edition, edited by B. Shortridge and J. Shortridge, 201-213. Lanham, Maryland: Rowman and Littlefield Publishers, Inc.

Mogelonksy, M. 1998. "Food on Demand." American Demographics, January [journal on-line]; available from http://www.demographics.com/publications/ad/98_ad/ 9801_ad/ad980132.htm; accessed on 18 April 2000.

Morgan, L. 1992. "Regional Essay: Northwest Washington and the San Juan Islands." In The Good Food Guide To Washington and Oregon, edited by L. Morgan, 1-5. Seattle, Washington: Sasquatch Books.

Murphy, A. 1991. "Regions as Social Constructs: The Gap Between Theory and Practice." Progress in Human Geography 15(1): 22-35.

Nims, C. and L. McKean. 1996. The Northwest Best Places Cookbook: Recipes from the Outstanding Restaurants and Inns of Washington, Oregon, and British Columbia. Seattle, Washington: Sasquatch Books.

Nolan, M. 1993. "Historical Geography." In Atlas of the Pacific Northwest, $8^{\text {th }}$ edition, edited by P. Jackson and A. Kimerling, 7-18. Corvallis, Oregon: Oregon State University Press.

Oregon Tourism Commission and the Portland Oregon Visitors Association. 1999. "Oregon in Season." Gourmet, April, Special Advertising Section, not paginated.

Page-English, M. 1992. "A Corner for Hazelnuts." In The Good Food Guide to Washington and Oregon, edited by L. Morgan, 139-40. Seattle, Washington: Sasquatch Books.

Pilcher, J. 1998. Que Vivan los Tamales: Food and the Making of Mexican Identity. Albuquerque, New Mexico: University of New Mexico Press.

Pillsbury, R. 1998. No Foreign Food: The American Diet in Time and Place. Boulder, Colorado: Westview Press. 
Pisegna, D. 1990. Food for All Seasons: Savory Recipes from the Pacific Northwest. San Francisco: Chronicle Books.

Pocock, D. 1994. "Place and the Novelist.". In Re-Reading Cultural Geography, edited by K. Foote, P. Hugill, K. Mathewson, and J. Smith, 363-373. Austin, Texas: University of Texas Press.

Robbins, W. 1983. "Introduction." In Regionalism and the Pacific Northwest, edited by W. Robbins, R. Frank, and R. Ross, 1-9. Corvallis, Oregon: Oregon State University Press.

Sarich, J. 1993. Food and Wine of the Pacific Northwest. Seattle, Washington: Sasquatch Books.

Sarasohn, D. 1993. "Summit Food: A Peak Experience." The Oregonian, 2 April, sec. A\&E, p. 30.

Sarasohn, D. 1999. "Pretty in Pink." The Oregonian, 31 December, sec. A\&E, p. 14.

Schnetzer, A. 1999. "The Golden Age of Cooking." Policy Review, October/November [journal on-line]; available from http://proquest.umi.com; accessed on 14 December 1999.

Schwantes, C. 1996. The Pacific Northwest: An Interpretive History, revised edition. Lincoln, Nebraska: University of Nebraska Press.

Scott, J. and R. De Lorme. 1988. Historical Atlas of Washington. Norman, Oklahoma: University of Oklahoma Press.

Skott, M. and L. McKean. 1995. Pacific Northwest Flavors: 150 Recipes from the Region's Farmland, Coastline, Mountains, and Cities. New York: Clarkson Potter Publishers.

Shortridge, B. and J. Shortridge. 1989. "Consumption of Fresh Produce in the Metropolitan United States." Geographical Review 79(1): 80-98.

Shortridge, B. and J. Shortridge. 1998a. "Introduction: Food and American Culture." In The Taste of American Place: A Reader on Regional and Ethnic Foods, paperback edition, edited by B. Shortridge and J. Shortridge, 1-18. Lanham, Maryland: Rowman and Littlefield Publishers, Inc. 
Shortridge, B. and J. Shortridge. 1998b. "Patterns of Rice Consumption 1955 and 1980." In The Taste of American Place: A Reader on Regional and Ethnic Foods, paperback edition, edited by B. Shortridge and J. Shortridge, 85-100. Lanham, Maryland: Rowman and Littlefield Publishers, Inc.

Shortridge, B. and J. Shortridge, eds. 1998c. The Taste of American Place: A Reader on Regional and Ethnic Foods, paperback edition. Lanham, Maryland: Rowman and Littlefield Publishers, Inc.

Shortridge, J. 1998. "The Persistence of Regional Labels in the United States: Reflections from a Midwestern Experience." In The New Regionalism, edited by C. Wilson, 45-63. Jackson, Mississippi: University Press of Mississippi.

Sokolov, R. 1991. Why We Eat What We Eat: How the Encounters Between the New World and the Old Changed the Way Everyone on the Planet Eats. New York: Summit Books.

Starke, A. 1999. "Food Industry Questions Fishing Crisis, Practices." The Oregonian, 6 April, sec FD, p. 2.

Steiner, M. and D. Wrobel. 1997. "Many Wests: Discovering a Dynamic Western Regionalism." In Many Wests: Place, Culture, and Regional Identity, edited by D. Wrobel and M. Steiner, 1-30. Lawrence, Kansas: University of Kansas.

Taggart, D. and K. Taggart. 1998. Northwest Food and Wine: Great Food to Serve with the Wines of Oregon and Washington. Seattle, Washington: Sasquatch Books.

Thompson, C. and D. Newman. 1999. "You Eat What You Are? Social Identity and Food Among American College Students." In Cultural and Historical Aspects of Foods, Yesterday, Today, and Tomorrow: Proceedings of the Conference in Corvallis, Oregon, April 9-11, 1999, by the Department of Nutrition and Food Management, College of Home Economics and Education, Oregon State University, 222-234. Corvallis, Oregon: Oregon State University.

Tuan, Y. 1980. "Rootedness Versus Sense of Place." Landscape 24(1): 3-8.

Tuan, Y. 1996. Cosmos and Hearth: A Cosmopolite's Viewport. Minneapolis, Minnesota: University of Minnesota Press.

Walla Walla Sweet Onion Commission. n.d. "A Sweet Tradition" [web site]; available from http://www.home.bmi.net/onions/Tradition/tradition.html; accessed on 28 March 2000. 
Ward, C. 2000. "Southern Cuisine Sits on African Influences." The Oregonian, 22 February, sec. FD, p. 10.

Washington Department of Agriculture. 1999. 1999 Annual Bulletin [report on-line]; available from http://www.nass.usda.gov/wa/annual99; accessed on 27 March 2000 .

Williams, J. 1996. The Way We Ate: Pacific Northwest Cooking, 1943-1900, paperback edition. Pullman, Washington: Washington State University Press.

Zelinsky, W. 1998. "You Are Where You Eat." In The Taste of American Place: A Reader on Regional and Ethnic Foods, paperback edition, edited by B. Shortridge and J. Shortridge, 243-250. Lanham, Maryland: Rowman and Littlefield Publishers, Inc. 
APPENDIX

RESTAURANT SURVEY

Name of your establishment:

What year did your restaurant open?

Briefly describe the type(s) of cuisine your restaurant serves:

Do you serve Pacific Northwest cuisine or dishes that you feel represent the region?

$$
\square \text { yes } \quad \square \text { no }
$$

If you were planning a menu that best represents the Pacific Northwest, what would it include?

What percentage of your wine list comes from the Pacific Northwest?
$\square 10 \%$
$\square 25 \%$
$\square 50 \%$
$\square 75 \%$
$100 \%$

What percentage of you beer list comes from the Pacific Northwest?
$10 \%$
口 $25 \%$
$\square 50 \%$
$\square 75 \%$
$100 \%$

Do you buy produce from local farmers?
$\square$ yes
$\square$ no

If so, for how long?
$\square$ less than 6 months
6 months to 1 year
4 to 5 years
$\square 1$ to 2 years
2 to 3 years
$\square 5+$ years 


\section{RESTAURANT SURVEY}

(continued)

How many local farmers do you currently buy from?
a 1
$\square 2$ to 5
a 6 to 10
$\square$ more than 10

What types of produce do you buy from them? Please check all that apply.

$\begin{array}{llll}\square \text { salad greens } & \square \text { root vegetables } & \square \text { orchard fruits } & \square \text { berries } \\ \square \text { nuts } & \square \text { grains } & \square \text { melons } & \square \text { herbs } \\ \square \text { garlic/onions } & \square \text { squash } & \square \text { other }\end{array}$

Would you or another representative from your establishment be willing to take part in a follow up interview that would last approximately a $1 / 2$ hour?

$\square$ yes $\square$ no

If you prefer not to be interviewed, can I contact you by e-mail for some follow-up questions? Please provide your e-mail address if you answer yes.

$\square$ yes $\square$ no e-mail address:

Would you allow the researcher to look at menus from the previous year?

$\square$ yes $\quad \square$ no

Would you allow the researcher to place a small postcard survey (for your patrons) somewhere in your restaurant (see attached)?
$\square$ yes
$\square$ no

If you wish to further participate in this study in any of the above capacities please provide the following. All names of participants will be kept confidential.

Contact Person:

Best time to contact you (day/time): 


\section{INTERVIEW QUESTIONS}

1) Please define "regional cuisine?" Or, what distinguishes a cuisine as regional?

2) What role(s) do regional cuisines play in people's lives other than "filling their tummies?"

3) What are, if any, the cuisine regions of the United States? (I will have a map of the United States and ask the respondent to circle or outline each region.)

If the respondent doesn't distinguish a PNW cuisine region, ask why he/she doesn't think there is a PNW cuisine?

4) If respondent does, ask what he/she thinks distinguishes PNW cuisine from other regional cuisines (for example, California Cuisine)?

5) What (if any) social, cultural, and ethnic contributions, or historical events, have helped shape or contributed to PNW cuisine?

6) At what point was the PNW recognized as having a regional cuisine? By whom?

7) If there is mention of "fresh \& local" as distinctive characteristics, ask how this contributes to regional cuisine? Is this not a popular trend throughout the US?

8) Do you think there is a relationship between the growth of the wine industry in the PNW and regional cuisine (food-wine matching)?

9) Do your customers consciously seek out PNW cuisine (not relevant to every interview)?

10) Do you think there is a "food icon" for the region? If so, what is it? Why this particular foodstuff? What does it "say" about the PNW? If not, why not?

11) Clarify survey responses:

Local farmers: direct or distributor; if direct, ask for a brief description of arrangement/relationship between chef \& farmer

Foragers? 